\title{
EMPLOYEE OWNERSHIP, BOARD REPRESENTATION, AND CORPORATE FINANCIAL POLICIES*
}

\author{
Edith Ginglinger \\ Université Paris-Dauphine, DRM \\ William Megginson \\ Professor and Rainbolt Chair in Finance \\ University of Oklahoma \\ Timothée Waxin \\ Université Paris-Dauphine, DRM
}

$\underline{\text { Journal of Corporate Finance, } 2011,17,868-887}$

\begin{abstract}
French law mandates that employees of publicly listed companies can elect two types of directors to represent employees. Privatized companies must reserve board seats for directors elected by employees by right of employment, while employee-shareholders can elect a director whenever they hold at least 3\% of outstanding shares. Using a comprehensive sample of firms in the Société des Bourses Françaises (SBF) 120 Index from 1998 to 2008, we examine the impact of employee-directors on corporate valuation, payout policy, and internal board organization and performance. We find that directors elected by employee shareholders increase firm valuation and profitability, but do not significantly impact corporate payout policy. Directors elected by employees by right significantly reduce payout ratios, but do not impact firm value or profitability. Employee representation on corporate boards thus appears to be at least value-neutral, and perhaps value-enhancing in the case of directors elected by employee shareholders.
\end{abstract}

\footnotetext{
* We thank Franklin Allen, Eric de Bodt, Bernardo Bortolotti, Henrik Cronqvist, François Degeorge, Diane Denis, Mara Faccio, Larry Fauver, Chitru Fernando, Janya Golubeva, Ulrich Hege, Gerard Hertig, Matthew Morey, Jeff Netter (the editor), Vahap Uysal, Pradeep Yadav, Tina Yang, Hong Feng Zhang, an anonymous referee, and participants in the Australasian Finance and Banking Conference, Sydney, Australia (December 2008), the 2009 INFINITI conference (Trinity College, Dublin), the 2009 Financial Management Association meeting, and the University of Oklahoma seminar series for helpful comments on this paper. This study was initiated while Bill Megginson was the Fulbright Tocqueville Distinguished Chair in American Studies at the Université ParisDauphine, and the financial support of the Fulbright Commission and of the Fédération Bancaire Française Chair in Corporate Finance is gratefully acknowledged.
} 


\title{
EMPLOYEE OWNERSHIP, BOARD REPRESENTATION, AND CORPORATE FINANCIAL POLICIES
}

\begin{abstract}
French law mandates that employees of publicly listed companies can elect two types of directors to represent employees. Privatized companies must reserve board seats for directors elected by employees by right of employment, while employee-shareholders can elect a director whenever they hold at least $3 \%$ of outstanding shares. Using a comprehensive sample of firms in the Société des Bourses Françaises (SBF) 120 Index from 1998 to 2008, we examine the impact of employee-directors on corporate valuation, payout policy, and internal board organization and performance. We find that directors elected by employee shareholders increase firm valuation and profitability, but do not significantly impact corporate payout policy. Directors elected by employees by right significantly reduce payout ratios, but do not impact firm value or profitability. Employee representation on corporate boards thus appears to be at least value-neutral, and perhaps value-enhancing in the case of directors elected by employee shareholders.
\end{abstract}

JEL Classification: G32, G35, G38, J54, J83

Keywords: Employee Ownership, Payout Policy, Privatization, Corporate Boards 


\section{Employee Ownership, Board Representation, and Corporate Financial Policies}

\section{Introduction}

Should employees be allocated control rights in the companies for which they work? This question has long been debated, but has picked up impetus recently as societies have struggled to balance worker rights with effective corporate governance. While the collapse of communism has removed the most extreme examples of employee ownership, Germany and other countries mandate that workers be represented on corporate boards, and most western democracies encourage employee share ownership through tax, compensation, and pension policies. However, it is still unclear whether employee ownership or representation on the corporate board of directors increases firm value or productivity. This study exploits a natural experiment in mandated employee representation conducted in France--a major western country with both a market economy and a long tradition of robust worker employment protection- to determine whether giving workers control rights without cost to them creates value, and whether directors elected by employees who are also shareholders have a differential impact on firm value than do directors elected by workers as a right of employment.

Employing a sample of French companies provides a unique institutional setting for empirical analysis. French law mandates that employees of large publicly listed companies be allowed to elect directors for two reasons. First, privatized companies must reserve two or three (depending on board size) board seats for directors elected by employees by right of employment. Since privatized firms are easily the largest and most valuable companies in France, this requirement induces significant representation on the boards of an important and highly visible group of companies by directors elected by workers who are not also shareholders. Second, employee-shareholders in any publicly listed firm have the legal right to elect one director whenever they hold at least $3 \%$ of outstanding shares. Additionally, French law allows but does not mandate that listed firms may adopt a two-tiered supervisory and management board structure, as per the German model. Taken together, these regulations and governance options have engendered employee representation on the boards of over one-fifth of the largest French companies, but have also created significant cross-sectional variation in the extent and type of employee board representation. Examining large French companies also allows us to study whether varying levels of employee representation impacts firm value and performance differentially than does the fixed representation mandated by Germany and, most importantly, whether employee representatives elected by right act and impact firm policy differently than do representatives elected by employee-shareholders and by shareholders who do not work for the company. Our sample further allows us to directly test whether directors elected by employees by right reduce corporate payouts and whether directors elected by 
employee-shareholders act like other employees or act instead as value-maximizing shareholders who recognize the need for the firm to pay an adequate cash return to its investors.

Finally, our sample enables us to examine how the differing types of employee board representation impact the size and meeting frequency of corporate boards. Since privatized companies or those that acquired a privatized firm are required to offer board representation to employees as a right, there is no presumption that these directors' positions would be created absent a legal mandate. Thus, firms which must offer these seats should have larger boards than do otherwise similar, non-privatized companies that are allowed to set board size in a value-maximizing manner. Additionally, directors elected by employees by right are union representatives who are paid their normal wage for attending board meetings, but must pass on the union the directors' fees they receive. This fact alone should make directors elected by right relatively more eager to attend board meetings than are directors elected by shareholders, since their opportunity cost of time is lower, and this tendency will be accentuated if directors elected by right see board meetings as a means to lobby managers for higher pay or other employee conditions.

Using a comprehensive sample of firms in the Société des Bourses Françaises (SBF) 120 Index from 1998 to 2008, we study the financial impact of the two types of employee representation. We find that directors elected by employee shareholders significantly increase firm valuation and profitability, but do not significantly impact corporate payout (dividends and share repurchases) policy or board organization and performance. This value-enhancing effect of employee-shareholder representation remains after adjusting for endogeneity, after excluding privatized firms from the sample, and after performing numerous other robustness checks. Directors elected by employees by right significantly reduce payout ratios, and increase board size, complexity, and meeting frequency-but do not significantly impact firm value or profitability. These representatives are usually observed only in privatized companies or in companies that acquired privatized firms in the recent past, so an important question is whether our key finding of reduced payouts resulting from elected employee representation on the board of directors is simply a residual from examining privatized companies. We perform multiple robustness checks and verify that elected employee representation reduces payout even when we control for former state owned firms, when we use firm fixed-effect regressions, and when we instrument for employee representation using two-stage least squares. We also find that companies with directors elected by right by employees have larger boards than do other companies and these boards meet significantly more frequently. On balance, employee representation on corporate boards seems to be at least valueneutral, and may actually increase firm valuation and profitability when employee-shareholders elect company directors. 
This paper is organized as follows. Section 2 surveys the literature on employee ownership and corporate board representation, while section 3 describes the French institutional background and the laws mandating different types of employee representation. Section 4 describes our sample and presents univariate analyses of the impact of the two types of employee board representation on corporate valuation, financial policies, and internal board organization and performance. Section 5 presents regression analyses of these effects, while section 6 presents robustness checks, adjusts for endogeneity, and discusses the implications of the study's key findings. Section 7 concludes.

\section{Theoretical motivation and hypotheses development}

In this section, we discuss the theoretical and empirical literature on the impact of employee ownership and representation on firm value and financial decisions.

\subsection{Employee participation in governance and firm value}

It is not clear whether employee participation in corporate governance should increase or decrease firm value. Alchian and Demsetz (1972) show that, when there is perfect information, control rights should optimally be entrusted in one agent, the firm's owner. Jensen and Meckling (1976) show that agency problems arise whenever there is a separation of ownership and control and that institutional arrangements arise to ameliorate these costs. Fama and Jensen (1983a) examine the governance problems that arise when ownership and control are separated, as occurs naturally in most large companies, and describe the optimal allocation of control rights to residual claimants when this occurs (Fama and Jensen,1983b). These theoretical works suggest that the limited-liability public corporation--with nearly complete separation between professional managers and risk-bearing shareholders, who can feely trade their shares on public stock markets-probably has greater survival value in complex modern economies than does any competing organizational form.

The theoretical antithesis of the public corporation is a company owned and operated by workers, and there is a substantial stream of research examining whether labor managed firms can ever be competitive. The most influential early analysis of labor managed firms was presented in Jensen and Meckling (1979), who described the organizational, contracting, and commitment problems they predict must naturally arise when labor is made the owner/manager of corporate assets. These authors also make the insightful observation that the best evidence against the viability of labor managed firms is that these are never observed except where mandated by law_and even where mandated Jensen and Meckling assert that corporations expend great time and energy trying to escape the strictures imposed by this format. The practical and theoretical case against pure labor managed firms thus seems compelling. 
On the other hand, a better case can be made for a hybrid form of corporate governance, where shareholders are accorded dominant control rights over a corporation, but where employees and other stakeholders are given a direct and meaningful choice. Allen, Carletti, and Marquez (2007) predict that such stakeholder-oriented firms, which are concerned with employees and suppliers in addition to shareholders, will often prosper in competition with purely shareholder-oriented firms, though they also predict that the cost to consumers from such less-than-purely competitive behavior may be high. Claessens and Ueda (2008) present empirical evidence supporting this prediction, though Lee, Liu, and Zhu (2008) show that employees suffer financially from over-investing in their employers' stocks.

\subsubsection{Expected benefits from employee participation in corporate governance}

Economic theorists have posited three principal reasons why direct employee participation in corporate governance can be value-maximizing, and each of these predictions has garnered at least some empirical support. First, Freeman and Lazear (1995) predict that having worker representation on corporate boards will allow more effective information transfer from board to workers. Workers' representatives get precise information on the firm's actual situation which could make employees more ready to cooperate and work hard when needed.

The second reason why worker board representation may increase value is that this promotes better information transfer from employees to other board members. Acharya, Myers, and Rajan (2010) point to the critical monitoring role that highly productive, but non-executive, employees can play in constraining self-serving actions by senior managers, even absent any external governance, since these employees bring detailed company-specific knowledge to the boardroom, and since the human capital they have tied up in the company gives them strong incentives to ensure that the company is managed in a sustainable manner. ${ }^{1}$

The third theoretical reason why workers should be accorded a direct say in firm governance is that employee representation will provide better motivation for workers and promotes convergence of interests between employees and shareholders. This presumes that the best way to get employees thinking as shareholders and working to maximize shareholders value is to let them becoming shareholders. The most common method of promoting employee stock ownership and participation in corporate governance is to encourage workers either to purchase stock directly, on their own accounts, or indirectly through employer-sponsored schemes. A logical corollary to this idea is that the alignment of incentives and

\footnotetext{
${ }^{1}$ Raheja (2005), Coles, Daniel, and Naveen (2008), and Gillette, Noe, and Rebello (2008) all predict that insiderdominated boards may have some competitive advantages over boards consisting principally of disinterested outsiders, while Galai and Wiener (2008) analyze the optimal allocation of board representation for companies confronting economic or financial distress.
} 
motivational effect will be greater when employees must actually purchase shares, rather than being granted board seats by right. This is most comparable to the requirement in French law that employeeshareholders must be granted board representation when their ownership exceeds a certain level.

\subsubsection{Expected costs of employee participation in corporate governance}

While there is theoretical support for worker participation in corporate governance, there are also several theoretical and practical arguments against it. The first such argument is that granting significant employee board representation will saddle the firm with all the adverse incentive and contracting problems associated with pure labor managed firms. This will be especially problematic if workers are given board seats without having to make a comparably sized financial investment-as is the case in French companies where workers acquire board seats by right of employment.

The second theoretical argument against worker representation on corporate boards is that this will complicate firm decision making. As Jensen and Meckling (1979) predict, workers will have strong reason to lobby the company's board to grant higher pay and other rents since workers will profit from this at shareholders expense, but will bear few of the costs of diverting corporate cash flows. Tirole (2001) also shows that developing a stakeholder society—wherein a company's investors, employees, suppliers, and customers all have a say in corporate governance--is very difficult to create because of the dearth of pledgeable income, deadlocks in decision-making, and the lack of a clear mission for management. Employees also may favor corporate policies that reduce the likelihood of default, as they will loose their job in case of default. Berk, Stanton, and Zechner (2009) propose a model in which human capital costs associated with financial distress and bankruptcy are large enough to be a disincentive to issue debt. Thus, one direct way that unions may affect firm value is by inducing managers to undertake less risky investments.

Finally, granting employees board representation increases the likelihood that workers will be enlisted as an anti-takeover device to protect entrenched managers from discipline by shareholders. Pagano and Volpin (2005) model this tendency of managers to enlist workers as allies, and Bertrand and Mullainathan (2003), Atanassov and Kim (2009), and Cronqvist, Heyman, Nilsson, Svaleryd, and Vlachos (2009) document a tendency for managers who are insulated from takeovers-through the influence, respectively, of U.S. state business combination laws and concentrated personal share ownership of Swedish managers - to pursue the "quiet life" by paying workers higher than necessary wages and by monitoring employees less intensively.

\subsubsection{Empirical evidence on the net value of employee participation in corporate governance}


Most empirical analyses of the impact of mandated employee participation in corporate governance focus on the German system of codetermination. Germany's system is described and analyzed in Furubotn and Wiggins (1984), Levine and Tyson (1990), Freeman and Lazear (1995), and Allen and Gale (2002), while Fauver and Fuerst (2006) show that the system of Mitbestimmungrecht (right of codetermination) requires that workers receive one-half of all seats on the supervisory board (Aufsichgtrat) of German Aktiengesellschaft (AG), or publicly traded companies. A separate law mandates that workers receive one-third of board seats in companies with between 500 and 2000 workers, and various supplemental regulations have narrowed the scope for German companies to escape these codetermination strictures. Fauver and Fuerst (2006) present the most compelling empirical study supporting the proposition that codetermination may actually create value by conferring first-hand operational knowledge to corporate decision-making. Using a comprehensive sample of listed German companies in 2003 , they document that $51 \%$ have employee representation. While the median level of representation is one-third of board seats, over one-third of companies with representation show higher levels than legally required. Fauver and Fuerst show that firms with employee representation are consistently more profitable and are significantly more likely to pay out cash as a dividend than are companies without worker representation. They also find that Tobin's Q is significantly higher for firms with greater employee representation in industries that demand high levels of coordination-principally industries with complex supply chains. ${ }^{2}$

The evidence on employee stock ownership plans (ESOPs) also suggests that allowing workers to buy shares in their employers increases firm value. Tax laws, particularly in the United States, encourage firms to adopt ESOPs on their workers' behalves, and most of the empirical studies examining plan adoptions generally find that adoptions are associated with small, but significantly positive announcement period abnormal returns and modest long-term operating performance improvements. ${ }^{3}$

On the other hand, the most comprehensive analysis of the impact of labor voice on American public companies, by Faleye, Mehrotra, and Morck (2006), shows that worker representation has a dark

\footnotetext{
${ }^{2}$ On the other hand, several other studies that describe the workings of Germany's codetermination system and empirically analyze the German model reach conclusions similar to those foreshadowed by the Jensen and Meckling (1979) analysis of labor managed firms. Gorton and Schmid (2004) examine German companies with equal representation by employees and shareholders, and find that these companies trade at a $31 \%$ market discount compared to companies where employee representatives fill only one-third of the supervisory board seats. Interestingly, Fauver and Fuerst (2006) also find diminishing returns to employee representation over the level of one-third of board seats, though they conclude greater representation still creates value.

${ }^{3}$ Event study tests that document positive announcement period returns around ESOP adoption include Chang (1990), Faria, Trahan, and Rogers (1993), and Beatty (1995), while Gordon and Pound (1990) find insignificant announcement period returns. Studies examining the taxation and accounting implications of ESOP adoption include Chaplinsky and Niehaus (1990), Scholes and Wolfson (1990), Beatty (1995), and most recently, Kim and Ouimet (2009), who document that firms adopting small (less than 5\% of outstanding shares) ESOPs experience a significant increase in firm value, but companies adopting larger plans do not.
} 
side. They compare the valuation and financial performance of a sample of 255 "labor voice firms," in which employee ownership exceeds 5\% (and labor representatives, rather than managers, vote the employee shares), to a control sample of companies with employee ownership of less than 5\%. Compared to the control sample, labor voice firms have lower Tobin's Q, invest less in long-term assets, take fewer risks, grow more slowly, create fewer new jobs, and exhibit lower labor and total factor productivity. Chen, Kacperczyk and Ortiz-Molina (2010) also document two negative effects from allowing employees to have a voice in corporate policies. First, they find that firms in more unionized industries spend a smaller fraction of their investment budgets on risky R\&D than they do on physical assets. Second, they show that firms in more unionized industries have statistically lower bond yields, even after controlling for characteristics that are known to affect yields, due to unions influence on corporate affairs that serves as a mechanism that protects bondholders' wealth.

Based on the theoretical arguments and empirical evidence discussed above, we make the following two predictions about the relationship between employee board representation and firm value:

H1: Board representation by directors elected by employee-shareholders should have a positive impact on firm value.

H2: Board representation by directors elected by employees as a right of employment (without purchasing shares) should have a non-positive impact on firm value.

\subsection{Employee participation in governance and payout policy}

Compared to the theoretical and empirical literature examining the relationship between employee ownership/representation and firm value, very little research has examined how worker ownership/representation will affect corporate payout policies. The most straightforward prediction for labor managed firms - and for privatized French companies where employees are allowed to elect a significant fraction of a firm's directors by right of employment-comes from Jensen and Meckling (1979). They argue that worker representatives will lobby to retain corporate profits, rather than pay out the cash as dividends and share repurchases, since this increases the asset cushion backing labor's claim on the firm's cash flows. As dividends and, especially, repurchases financed through debt issues increase the risk of the firm (and potentially leverage), employees should prefer lower payouts.

The empirical evidence examining the relationship between employee representation and corporate payout is sparse. Using data from the restructuring of the U.S. steel industry during the 1980s, DeAngelo and DeAngelo (1991) show that dividend cuts enable firms to obtain concessions from unions by convincing them that shareholders themselves are forced to make sacrifices to alleviate the firm's financial difficulties. In their study of Germany's Codetermination system, Fauver and Fuerst (2006) find that firms with employee representation are more likely to pay dividends. 
Based on the theoretical arguments and empirical evidence discussed above, we make the following two predictions about the relationship between employee board representation and corporate payout policy:

H3: Board representation by directors elected by employee-shareholders should have a non-negative impact on corporate payouts through dividends and share repurchases.

H4: Board representation by directors elected by employees as a right of employment (without purchasing shares) should have a negative impact on corporate payouts through dividends and share repurchases.

\section{French law and employee representation on corporate boards}

Though partly inspired by Germany's codetermination model, the French employee representation system was launched three decades later and has evolved quite differently. The first such piece of legislation was the July 23, 1983 Law, passed by a left-wing government, which allowed worker representation on the board of directors of state-controlled companies (where the state owns more than $50 \%$ of the share capital). Depending on the total number of workers, employee-selected directors can represent up to one third of the members of the board. Three years later, the Ordonnance 21 Octobre 1986 allowed privately owned firms to change their statutes to have employees elected on the board. ${ }^{4}$ To date, however, this option has never been adopted by any large publicly traded company that was not once state-owned.

The Law of July 25, 1994 mandated that the statutes of the company being privatized should be modified before sale to reserve a certain number of seats on the board of directors for the representatives of employees. The specific required reservations were: (1) two seats for the representatives of the labour force as a whole and one seat for the shareholder employees if the board of directors is made up of less than 15 members; and (2) three seats for the representatives of the labour force as a whole and one for the shareholder employees if the board of directors consists of more than 15 members. However, once the company was privatized, shareholders could again change the firm's statutes to cancel the reserved seats for employee representatives on the board. This same law obliges companies, in which employees hold at least $5 \%$ of the capital, to submit to a vote of the general meeting a resolution giving one or more seats to directors representing employees (in addition to elected employees on the board), though the other

\footnotetext{
${ }^{4}$ The ordonnance specifically states that "The number of these directors cannot be higher than five, nor exceed one third of the number of the other directors. When the number of the directors elected by the employees is equal or higher than two, the 'engineers and managers' have at least one seat." The directors elected by the employees are not taken into account for the determination of the minimal number and the maximum number directors envisaged in article $89-3$ and 18 .
} 
shareholders could agree or disagree. The Law of February 19, 2001 reduces the previous threshold of $5 \%$ to $3 \%$.

The Law of January 17, 2002 went further, mandating that an employee director had to be nominated when employee ownership exceeds $3 \%$, not just that such a proposal had to be submitted for a vote at the general meeting. However, the companies whose board of directors already includes one or more directors who are members of the board of the employees' mutual funds or one or more employees elected are not obliged to nominate another employee representative.

As we show later, this law truly seems to have promoted board representation for employeeshareholders, as the fraction of companies with such directors increases sharply after 2001. In many companies (such as Alcatel, Vivendi, and Total), it is the president of the employee mutual fund who sits on the board. On the other hand, this law did not by itself prompt universal compliance, as implementing decrees and regulations were not immediately passed. Several CEOs were reluctant to nominate new directors representing employee-shareholders, in particular in cases where employees were already represented on the board by directors elected by employees as a right. For example, shareholderemployees of Société Générale are not represented on the board, even though they hold $7 \%$ of the capital and $12 \%$ of the voting rights. This suggests that managers are generally unwilling to promote increased employee board representation unless compelled by law to do so, especially when there are already directors elected (by right) to represent workers. We should also point out that both types of directors elected by employees (those elected by right and those elected by employee shareholders) have the same voting and other rights and responsibilities as do all other directors.

Privately owned firms (those that were never state-owned) can choose to have elected employees as directors, but never do. Most companies with employee ownership of at least 3\% have nominated a shareholder employee director. Privatized firms sold before 1993 that are no longer state owned face requirements similar to the ones that private companies face. Firms privatized after 1994 were obliged at the date of privatization to have two or three elected employees on the board, depending on the size of the board, plus one shareholder employee, but they could change their statutes whenever they wanted after being privatized. Finally, several privatized companies deleted one or both classes of employee representatives when they merged with other firms. ${ }^{5}$

Few companies explicitly voted to delete employee representation by non-shareholding employees in isolation (not as a result of merger or recapitalization). One company that did was Saint Gobain, which had two elected employees on the board until 1998. It proposed to the 1999 extraordinary

\footnotetext{
5 As examples, employee directorships on the board of Elf Aquitaine were not taken onto the board of Total when these two companies merged. The same occurred when Pechiney was purchased by Alcan or when Aventis (including formerly state-owned Rhône Poulenc) was bought by Sanofi. In fact, about one-third of all formerly stateowned companies dropped their employee representatives from their combined boards after merging.
} 
general meeting (two-thirds majority required) to cancel the requirement to have elected employees on the board. Shareholders agreed and from 1999 Saint-Gobain had no more employee-elected directors. The document submitted to vote explicitly said "ending the transitory period that began with privatization, we propose to..." Even with the deletions resulting from mergers and explicit votes, however, we will show that employee representation is far higher in formerly state-owned companies than in those that have always been private, and significantly higher in recently privatized companies than in those divested before 1994.

\section{Data and univariate results}

The sample of firms is drawn from the Société des Bourses Françaises (SBF) 120 Index and includes 201 unique firms covering 1,638 firm-years over the period 1998-2008. The SBF 120 Index regroups the 120 largest companies by market capitalisation and by trading volumes on Euronext Paris. Overall, 300 firm-year observations (18.3\% of the sample) have employee directors on their boards, 184 firm-year observations (11.2\% of the sample) have directors elected from among the employeeshareholders, and $172(10.5 \%)$ have directors elected by right by employees - so 56 firm-years (3.4\%) have both types of employee representatives on their boards.

Figure 1 shows the time trend of the percent of SBF 120 firms with employee directors and the percent of employee directors (PEMPEMPLOYEE for the total proportion, PEMP for the employees elected by right and PEMPSHARE for the shareholder employees) on boards from 1998 to 2008. Panels $\mathrm{A}$ and $\mathrm{B}$ report that while the percent of directors elected by right by employees on corporate boards remains quite stable over the study period, there is a continuous increase in the fraction of firms with employee-shareholder directors and in the fraction of all board seats they command-and these trends accelerate after $2001 .^{6}$ This observation reflects the direct impact of the Law of February 19, 2001 and the Law of January 17, 2002 and perhaps also mirrors the emergence of better governance practices, such as the introduction of more outside directors on corporate boards of directors, and the general promotion of employee ownership in companies. For example, Euronext and the Fédération Française des Associations d'Actionnaires Salariés et d'Anciens Salariés (FAS) launched the first employee shareholding index in the world in December 2006. This index is composed of all SBF 250 stocks having

\footnotetext{
${ }^{6}$ The variations in PEMP and PEMPSHARE have several sources: some privatized firms have dropped their elected employees by right (e.g. Saint-Gobain in 1999, Thomson in 2008), Other privatized firms have reduced the number of elected employees (e.g. France Telecom in 2004, Société Générale in 2006). In some cases, PEMP varies due to a variation in the size of the board (e.g. Aventis in 2002, Suez in 2004). Similarly, the proportion of shareholder employee directors vary due to new nominations (e.g. Total in 2004 and Sagem in 2006) or to reduction of the number of these directors (e.g. Groupe Steria in 2007 and Essilor in 2008), or to variation in the board size.
} 
a significant percentage of employee shareholding — defined as at least 3\% of the company's stocks being owned by more than one-fourth of its employees. ${ }^{7}$

\section{$* * * *$ Insert Figure 1 about here $* * *$}

The largest company with directors elected by right by employees is BNP Paribas; these directors account for $13 \%$ of its board in 2008. The largest company to have directors elected by employeeshareholders is the insurer AXA, which in 2006 has a board where such directors account for $7 \%$ of all seats. The company which has the highest fraction of directors elected from among the employees on the board is Air France in 2000 with a fraction of 35\%. Finally, the company with the highest fraction of directors elected by employee-shareholders is Essilor International, with 27\% in 2003.

Data on corporate boards is extracted from registration documents available on the Autorité des Marchés Financiers (AMF) website, on the Thomson One Banker database, or on the Internet websites of individual companies. In some cases we use "Rapports de contrôle interne et de gouvernement d'entreprise," which are available on the AMF website.

Information displayed in registration documents or in annual reports is not always accurate, especially for years before 2001. After that year, new regulations forced companies to publish more details on the composition of their boards. Several databases have been used to fill in missing biographical information of directors (such as gender, age, nationality, academic background), including "Who's Who," "Guide des Etats-Majors des Grandes Entreprises," and press issues available from the Factiva and LexisNexis databases and other Internet sites. We decide whether directors are insiders or independent using the criteria presented by Viénot $(1995,1999)$ and Bouton (2002), who define independent directors as directors who "do not have any links with the company, its group or management liable to affect their unbiased judgement."

Economic and financial data have been collected from the Worldscope database. Other sources of information or databases have been used in some cases, such as registration documents and annual reports and the Diane and Stockproinfo databases. For most of our multivariate tests, we follow La Porta, et al. (2000) and Faccio, et al. (2001), and exclude firms with negative net income, negative cash flow and firms whose dividends exceed net income, sales and cash flow.

We present detailed definitions of the firm, ownership, and board variables used in our tests and regressions in the Appendix.

\footnotetext{
${ }^{7}$ See http://www.euronext.com/trader/charts/chartsAnalyses-2834-EN-FR0003999598.html?selectedMep=1. During the period covered by our study, this index out-performed its main comparators (the SBF 250 and CAC 40 indices), but has under-performed since mid-2008.
} 


\subsection{Industrial breakdown of sample firms}

Table 1 describes the industrial breakdown of the firms that are included in the SBF 120 over 1998-2008. Manufacturing accounts for easily the largest fraction (36.6\%) of all firm-year observations, while agriculture, mining, and construction account for the smallest (6.23\%). Business and personal services represent almost one-fifth (18.6\%) of all observations, while wholesale and retail trade, finance, and the transportation, communications and utilities sectors account for $10.7 \%, 13.8 \%$, and $14.1 \%$ of all observations, respectively.

**** Insert Table 1 about here $* * * *$

We should note again that privatized firms are extremely important in France, and 366 of all firmyear observations $(22.34 \%)$ are of fully or partially privatized companies or firms that acquired at least one major formerly state owned firm. These are heavily over-represented among the very largest companies in the SBF every year and for the entire 1998-2008 study period. 55.46\% (203 of 366) of these firm-year observations are for companies that were privatized less than ten years before the observation year, while the remaining $44.54 \%$ (163 observations) are for companies privatized more than ten years previously. There were several privatizations during our sample period: Credit Lyonnais and Air France in 1999, Autoroutes du Sud de la France in 2002, Autoroutes Paris Rhin Rhône and Snecma in 2004, Gaz de France and Electricité de France in 2005 and Aéroports de Paris in 2006. The French state owns an average (median) $20.85 \%$ (2.03\%) of the stock of companies that were privatized recently, while the state owns only an average (median) 7.14\% (0\%) of the companies privatized more than 10 years previously. 1,272 firm-year observations are for companies that were never state-owned, though the French state still owns an average $1.10 \%(0 \%)$ of the stock of these firms. ${ }^{8}$ State ownership declines monotonically with time after the initial privatization sale.

\subsection{Univariate analyses}

As a first look at how firms with employee directors differ from other large French companies, we perform univariate comparisons. These are presented in Table 2. The first four columns of data compare mean and median values for firms, with and without any types of employee-directors, while the next four columns present comparisons of firms with and without employee-directors elected by right, and the last four columns present firms with and without directors elected by employee-shareholders. Univariate tests are reported for the test for equality of means (Student-t test) and the test for equality of medians (Wilcoxon test) between firms having directors elected from among the employees or from among the employee-shareholders, and firms which don't have these characteristics.

\footnotetext{
${ }^{8}$ The French state actually owns these stakes through the CDC, or Caisse des dépôts et consignation, which is a state institutional investor similar to a modern sovereign wealth fund.
} 


\section{***** Insert Table 2 about here ****}

Firms with all types of employee-directors are highly significantly larger than those without (average $€ 136.0$ billion compared to $€ 14.1$ billion, median $€ 24.6$ billion compared to $€ 1.9$ billion), and firms with directors elected by employees by right are the largest of all (average $€ 190.0$ billion, median $€ 29.8$ billion). This is unsurprising, since these tend to be recently privatized companies or companies that bought privatized firms. The average (median) book-value leverage ratio for the entire sample is $25.82 \%$ (24.28\%), and there is no significant difference in leverage ratios between any groups based on whether or not they have employee directors. Firms without employee directors have significantly higher tangible asset ratios than all categories of firms with employee-directors. They also have higher capital expenditure ratios. Tobin's Q and MTB are significantly lower for firms with employee directors (both) compared to firms without. Companies without employee representation on boards also grow significantly more rapidly than do those with employee directors. There are generally no significant differences between firms with and without employee directors with respect to mean payout ratios (PAYOUT), although median payout is higher for firms with elected directors compared to firms without. On the other hand, firms with employee directors are significantly older than firms without such representation and have significantly larger boards that meet significantly more frequently and have significantly more standing committees. These observations are directly linked to the large size of the firms. ${ }^{9}$

The average size of corporate boards without employee representation is 9.8 directors, significantly smaller than the 15.2, 16.0, and 14.7 member boards of companies with any type of employee-directors, those with directors elected by right, and those with directors elected by employeeshareholders, respectively. Further, boards with directors elected by the employees have fewer independent directors (35\% versus 43\%), whereas firms with employee-shareholder directors do not differ from firms without. The median fraction of women directors is higher in firms with directors elected by right and in firms with directors elected by employee-shareholders than in companies without employee directors. The boards of firms without employee directors meet an average of 7.0 times per year and have an average of 1.9 standing committees, while companies with employee directors meet on average 7.8 times per year and have a mean 2.9 standing committees. The mean and median values for both number of meetings and number of committees are significantly larger for firms with directors elected by right compared to companies with directors elected by employee-shareholders. Thus,

\footnotetext{
${ }^{9}$ Hermalin and Weisbach (1998) and Linck, Netter, and Yang (2008) suggest that, other things equal, smaller boards are generally better, though Coles, Daniel, and Naveen (2008) show that the actual relationship between board size and performance is much more complex and dependent upon the type of firm in question and its investment opportunity set.
} 
companies with board members representing employees have significantly larger, more complex, and more active boards than do companies without employee representatives.

As noted above, French corporate law allows firms to select a two-tiered board, and we find significant differences between firms with and without employee board representation for both variables. Companies without employee representation are, on average, 2.5 times more likely to have a two-tiered board than are firms with employee directors, with $32 \%$ of the former having supervisory boards versus $13 \%$ in the latter. Firms with employee and employee-shareholder directors on their boards have greater state ownership than their counterparts. However, family ownership is lower in these firms. Results remain robust when we use voting rights (both in univariate and multivariate tests) rather than shareholdings. ${ }^{10}$

In sum, these univariate comparisons suggest that, compared to companies without employee board representation, firms with employee-directors are larger, older, less profitable, have more intangible and fewer tangible assets, have larger and more complex boards that meet more frequently, and are less likely to have a two-tiered board structure. Furthermore, the univariate analyses reveal little difference in observed financial policies between companies with directors elected by employees as a matter of right and companies with directors elected by employee-shareholders. Naturally, univariate comparisons can only tell us so much, so we now employ regression analyses to examine the impact of employee directors on corporate valuation and financial policies.

\section{Methodology and regression results}

Our multivariate analyses consist of a series of regressions, with which we examine how employee representation impacts corporate valuation, payout policy, and board of director performance. We measure valuation using two ratios, Tobin's Q (QTOBIN) and return on assets (ROA). Payout is measured variously as cash dividend payments divided by net income (PAYOUT), share repurchases divided by net income (REP/NETINC), and the combined value of cash dividends and share repurchases divided by net income (CREP/NETINC), market value (CREP/MV) and cash flows (CREP/CF). We report all measures but focus our comments on total payout divided by net income (CREP/NETINC). We next discuss the effect of employee directors on the annual frequency of board of director meetings (MEETINGS). On the one hand, an increased number of meetings may enhance monitoring and lead to better performance. For example, Vafeas (1999) finds that years with an abnormally high meeting frequency are followed by improvements in operating performance. On the other hand, board meetings

\footnotetext{
${ }^{10}$ All our tests are done with direct cash flow rights. We verified that they remain similar with direct voting rights, which allows us to account for "double voting rights," the main device used by French firms to dissociate voting rights and cash flow rights. This involves allowing shareholders who own stock for more than two years to double their per-share voting power, and is observed in a majority of large publicly traded French firms.
} 
are inherently costly in terms of management time and attention, the direct financial and staff resources committed to meetings and the potential distraction of firm efforts from value creation to consensus building. If there are sharply divergent interests represented on the board — as can easily be envisaged between profit-oriented shareholder representatives and ideologically motivated union representatives, or between founding-family representatives and professional managers - the costs of frequent board meetings might well be significant.

\subsection{The impact of employee board representation on firm value}

Table 3 presents the results of estimating the impact of employee ownership on firm valuation and profitability. We perform both ordinary least square regressions and firm fixed-effect panel regressions to control for unobserved, firm-specific characteristics such as strength of governance, corporate culture and managerial preferences and abilities. Columns 2-4 of Table 3 present estimations of Tobin's Q, while columns 5-10 present estimations of ROA, calculated both as operating income divided by assets - which is the European standard definition of ROA and the one referenced by French managers and investors - and as net income divided by assets, which is the standard U.S. definition. Consistent with extant literature, both of these measures are significantly negatively related to firm size, suggesting that smaller companies have higher valuations and are more profitable. Also unsurprisingly, Tobin's Q and ROA are significantly positively related to the level of capital investment spending divided by total assets and both are also negatively linked to the level of tangible assets as a fraction of total assets. Tobin's Q (but not ROA) is positively related to volatility.

\section{**** Insert Table 3 about here $* * * *$}

Turning to the ownership structure and employee representation variables, we see that the fraction of directors elected by right by employees (PEMP) is significantly positively related to ROA, but only for some specifications, while the fraction of directors elected by employee-shareholders (PEMPSHARE) is significantly positively related to Tobin's Q and to both ROA measures, for OLS (and this result is robust to inclusion of a privatization dummy) and fixed-effect regressions. Employee ownership is significantly positively related to Tobin's Q for small values (EO lower than 3\%) and negatively related to Tobin's Q and ROA for large values (EO higher than 10\%), suggesting that small employee ownership increases value for shareholders but rising employee stock ownership reduces value, independent of whether this ownership is also reflected in board representation. Taken together, these results suggest that low levels of employee-shareholder representation on corporate boards are value-enhancing, but this effect diminishes 
as employee ownership increases. ${ }^{11}$ For low levels of employee ownership, there is more motivation for employees and their board representatives to bring inside information to the board, which is positive for monitoring managers. At high levels of employee ownership employee directors bring inside information, but employees also have more power and may seek large private benefits (higher wages), thus counterbalancing the positive monitoring effect. ${ }^{12}$

The separate effects of family and state ownership on firm value and profitability contrast sharply. Residual state ownership is insignificantly negatively related to Tobin's Q and is significantly negatively related to ROA in some specifications. Family ownership has a significantly positive (at the $5 \%$ significance level) impact on both Tobin's Q and ROA, but these results are not robust in fixed effects regressions, suggesting that they mainly capture other unobserved characteristics.

To summarize these results, we find that Tobin's Q is significantly higher for smaller firms with fewer tangible assets that spend more on capital investment and which have directors elected by employee-shareholders. Tobin's $Q$ is lower for companies with high levels $(\geq 10 \%)$ of employee share ownership. ROA is higher in smaller companies and in firms with high family ownership. High employee and state ownership both reduce ROA. ROA is higher where employee-shareholders elect one or more directors. This effect is economically significant. On average, PEMPSHARE is $10 \%$ for those firms with directors representing employee-shareholders, and the coefficient of PEMPSHARE is between 0.1162 and 0.1720 for regressions examining ROA (using operating income), so the marginal impact is comprised between 0.0116 and 0.0172 (an increase of $1.16 \%$ to $1.72 \%$ of the ROA), or a $10 \%$ increase in ROA. Finally, the fact that the adjusted $R^{2}$ is at least 0.14 in all regressions suggests that our estimation models are explaining a substantial fraction of the cross-sectional variation in valuation and profitability measures in this sample.

\subsection{The impact of employee board representation on payout policy}

Table 4 presents the results of estimating the impact of employee ownership on corporate payout policy. Columns 2-4 of Table 4 present estimations of cash dividend payments as a percent of net income (PAYOUT), columns 5-7 present similar findings for repurchases as a percent of net income (REP/NETINC), and columns 8-10 present these findings for combined dividends and repurchases as a percent of net income (CREP/NETINC). Columns 11 to 16 present combined dividends and repurchases

11 Fauver and Fuerst (2006) document a similar non-linear relationship between firm value and the fraction of employee board representation (not ownership), though they find that the positive impact of employee representation tails at a much higher level of implied influence - only after employee board representation exceeds $33.3 \%$.

${ }^{12}$ These findings are confirmed when we replace (in unreported results) the proportion of the board accounted for by employee directors with a dummy equal to one if a given kind of employee representative is on the board. As robustness checks, we also introduced $\mathrm{EO}$ and $\mathrm{EO}^{2}$ in place of $\mathrm{EO}<3$ and $\mathrm{EO} \geq 10$, and our results remained similar, confirming the non-linear relation. 
divided by cash flows (CREP/CF) and market value (CREP/MV), respectively. For each dependent variable, the first column presents OLS regressions without privatization dummy, the second column includes a privatization dummy to test for a specific, separate effect of employee directors that abstracts from the mere fact that the company was privatized, and the third one presents fixed-effect regressions. We perform firm fixed-effect regressions to control for unobserved factors that might impart a spurious correlation between annual PEMP values for a firm and its payout policies.

\section{***** Insert Table 4 about here $* * * *$}

Results for cash dividend estimations show both similarities and differences with existing empirical research. Consistent with prior research, we find that PAYOUT is strongly negatively related to firm growth and risk (measured by volatility over the previous year) and positively related to firm size. Additionally, PAYOUT is significantly negatively related to capital spending. On the other hand, ROA is not significantly related to PAYOUT in most regressions.

Columns 5-7 of Table 4 present results for estimating payout as share repurchases divided by net income (REP/NETINC). Consistent with existing literature [see Skinner (2008) for U.S. and von Eije and Megginson (2008) for European evidence] share repurchases are significantly positively related to firm size and, but only significantly so in fixed effects regressions, to profitability (ROA). Family ownership is significantly (at the 5\% level) negatively related to dividend payout and unsignificantly related to share repurchases, while state ownership has no significant effect in most regressions. Columns 8-12 presents estimations where payout is defined as the combined level of cash dividend payments as a percent of net income (CREP/NETINC), market value (CREP/MV) and cash flow (CREP/CF). ${ }^{13}$ Combined payout measures are significantly positively related to size (in almost all regressions), positively related to ROA (not significant in all regressions) and negatively related to volatility.

The impact of increasing board representation by employee-directors on payout variables is striking and highly informative. The fraction of directors elected by employees by right (PEMP) is significantly negatively related to PAYOUT (cash dividends) in the first column OLS regression. However, when including PRIV (a dummy equal to one when the firm was once state owned), or using fixed effect regressions, PEMP is no longer significant, meaning that the effect on payout is mainly due to the fact that the firm was previously state owned or to other unknown factors. However, when share repurchases are taken into account, either alone (column 5-7) or combined with cash dividends (column 8-16), the fraction of elected employee-directors has a significantly negative impact. These findings

\footnotetext{
${ }^{13}$ All these regressions have also been performed replacing PEMP and PEMPSHARE by dummies DEMP and DEMPSHARE, equal to one if the firm has elected employees or shareholder employee on the board, respectively. Our results remain qualitatively the same.
} 
highlight that elected employee-directors have a significant ability to discourage firms repurchasing their own shares and reducing the total amount of cash distributed to shareholders, since the reduction in share repurchases is not offset by any increase in dividend payments. Conversely, the presence of directors elected by employee-shareholders (PEMPSHARE) has no significant effect on dividend payout or share repurchases. These results suggest that directors who represent workers who are not also shareholders work to reduce the amount of cash distributed by the firm to outside shareholders, whereas directors representing employee-shareholders act in the interest of all shareholders and do not reduce payouts.

Taken together, these results show that both ownership structure and board representation materially and significantly influence corporate payout policies. The presence of directors elected by employees as a right (PEMP) always has a significantly negative impact on share repurchases. This effect is economically significant. The average value of PEMP for those companies that have employee-elected directors is $20 \%$ and the coefficient for total payout (dividends and repurchases) in the regressions are comprised between 0.30 and 0.70 depending on the specification. Thus, the marginal impact is about a 0.06 to 0.14 (6\% to $14 \%$ ) decrease in the amount of cash that is distributed to shareholders of firms with PEMP. This is consistent with employees who are not also owners acting to block cash distributions from firms that would benefit shareholders. On the other hand, directors representing employee-shareholders generally do not significantly impact corporate payout policies, and instead seem to have the same interests as directors representing outside shareholders.

Clearly, both of the relationships involving employee representatives on corporate boards and observed financial policies and outcomes (PEMPSHARE-value and PEMP-payout relationships) are economically as well as statistically significant.

\subsection{The impact of employee board representation on board meeting frequency}

We estimate the impact of employee representation on corporate board performance in two ways. First, we test whether worker representation on the board leads on average to more frequent board meetings. Second, we estimate the likelihood that directors will be elected by employees as a right and by employee-shareholders based on observable firm characteristics.

Table 5 presents the results of estimating average board meeting frequency, using a Poisson regression to explain the number of meetings. As discussed in Greene (2003), an OLS regression model is not suitable for a discrete-censored variable like MEETINGS as it provides biased and inconsistent estimations, so we use Poisson regressions instead. Many of the findings are fairly intuitive. For example, it is unsurprising that boards of companies that are larger and more risky as measured by volatility will meet significantly more frequently on average than will less complex boards of less risky firms, or that boards of more profitable companies will meet significantly less frequently than boards of more 
financially troubled firms. Greater complexity in the task of overseeing a company implies the need to assemble as a board more frequently to assess and adjust firm objectives, while the need to make such adjustments is less urgent when the current corporate plan is working-when profits are high.

\section{**** Insert Table 5 about here $* * * *$}

We find that board members elected by employees as a right are associated with significantly more frequent board meetings than are board members who represent shareholders, either employeeshareholders or outside shareholders. The coefficient on the continuous variable measuring the fraction of the board accounted for by workers (PEMP) is significantly positive in four out of six specifications. Directors elected by workers who are also shareholders do not increase the number of meetings. If we consider the number of meetings as a proxy for more monitoring, boards with elected employees will better control the CEO. These employees may reduce managerial discretion, as they have specific information on the firm that they may share with other directors. On the other hand, the larger number of meetings may also result from increased bargaining on wages and other employment characteristics. In that case, giving employees the right to elect a fraction of the board of directors may impose additional costs on the firm. These results are robust to the inclusion of PRIV (privatization dummy), meaning that the increased number of meetings is not due to the fact that the firm is a former state owned firm. However, PEMP is no longer significant when fixed effect regressions are run, meaning that other unknown factors may explain the increased number of meetings.

We also estimate the fraction of a corporate board that will be elected by employees. (We do not tabulate these results here, but they are available upon request.) Since the dependent variable is truncated at zero, Tobit regression is used to explain PEMP and PEMPSHARE. Both types of employee board representation are likely to be smaller when employee share ownership is positive but lower than $3 \%$ $($ EO<3). High state ownership (STATE) and the company being a privatized firm or having acquired a privatized firm (PRIV) are the other main determinants of elected employee representation. The rationale for the STATE and PRIV results are fairly obvious, since we know that employee representation is common in privatized companies. Further, elected employee representation is higher for large, low growth firms and for one-tier board firms. For shareholder employee representation, we find that EO equal to or greater than $10 \%$ increases board representation, which is also higher in companies with a onetier board. This suggests that employee representation is a result of political and legal forces, especially the amount of stock retained in privatized companies by the state and employees' own share ownership. Though political influences matter for both types of representation, the election of directors representing employees who are not also shareholders seems to be driven by more explicitly political factors and is more likely in the largest firms, which naturally tend to be privatized companies. 


\section{Robustness checks and discussion}

\subsection{Testing for endogeneity in financial policy choice}

The univariate and regression results presented above present a clear message that board representation granted to shareholder employees tends to be value-enhancing and unrelated to payout policies, generally supporting our hypotheses $\mathrm{H} 1$ and H3, while board representation by directors elected by employees by right tends to be value neutral but reduces payout, supporting hypotheses $\mathrm{H} 2$ and $\mathrm{H} 4$. Before accepting these findings as conclusive, however, we must subject them to robustness checks. In particular, there could be endogeneity in the choice of financial policies, especially payout policy, since PEMP is observed only in firms that were privatized or acquired a privatized companies - and is not always observed even in those firms, since some have eliminated employee directors elected by right. Our results in Table 3 and 4, testing for robustness when including PRIV and using fixed effects alleviate the concern that there is a spurious correlation between PEMP and the fact that the firms are formerly stage owned. Another possible source of endogeneity is the potential for reverse causality in the relationship between board representation by directors elected by employee-shareholders (PEMPSHARE) and valuation. We predict that employee-shareholder representation leads to superior performance and valuation, but it also possible that more profitable and valuable firms would attract greater employee ownership and more employees on the board.

We examine further both possible sources of endogeneity in this section. We investigate the PEMP-payout and PEMPSHARE-valuation relationships by employing a two-stage least squares (2SLS) regression. We instrument PEMP with the industry mean, the average fraction of directors elected among the employees in the firm's industry. We test this instrumental variable for its relevance (correlated with the endogenous variable PEMP) and validity (uncorrelated with the standard errors). We then instrument PEMPSHARE with industry mean PEMPSHARE. Again, this variable has the characteristics of relevant instrumental variables: they are correlated with the endogenous variable PEMPSHARE, yet uncorrelated with the standard errors. We find that these instruments yield highly significant predictions of the actual values of PEMP and PEMPSHARE.

The second stage results using industry median PEMP and industry median PEMPSHARE to instrument PEMP and PEMPSHARE, respectively, are presented in Table 6. Results for payout policy estimations are generally similar to the original unadjusted findings. As before, the fraction of directors elected by employees by right (PEMP) is significantly negatively related to all our measures of dividend policy (at the $5 \%$ or $1 \%$ levels). On the other hand, PEMPSHARE now has a consistently positive effect on payout, and this is significant for three of the five payout measures. These results suggest that directors who represent workers who are not also shareholders work to reduce the amount of cash distributed by the firm to outside shareholders, whereas directors representing employee-shareholders act as a 
counterforce to increase dividends and repurchases. Most of the other explanatory variables have similar coefficient signs and significance levels, after adjusting for endogeneity, as in the original unadjusted regression analysis. All our payout policy variables are significantly negatively related to firm volatility and to capital spending, and are positively related to size. Family ownership (FAM) has a consistent and usually significant negative impact on payouts, while state ownership (STATE) is significantly positively related to all but one payout measure.

\section{**** Insert Table 6 about here $* * * *$}

The results of estimating the impact of employee ownership on performance, controlling for endogeneity, are also similar to the OLS findings for most variables. We find a strong and significantly positive effect of PEMPSHARE on all three performance measures (Tobin's Q and ROA computed using net income and operating income). Though PEMP is not significantly related to Tobin's Q or ROA using net income, it is significantly negatively related (at the $10 \%$ level) to ROA measured as operating income divided by assets. We confirm that family ownership and low levels of employee ownership $(<3 \%)$ are positively related to value and performance, while high levels of employee ownership $(\geq 10 \%)$ are significantly negatively related. CAPEX remains significantly positively, and TANGIBLE remains significantly negatively related to all three performance and valuation measures.

\subsection{Privatized firms that eliminated PEMP representation}

If board representation by directors elected by employees by right do in fact reduce corporate payouts, then a straightforward prediction is that privatized companies should begin increasing payouts once these directors' positions are eliminated. We test this proposition by including in the OLS regressions a new variable ELIMINATION that takes a value of 1 after a company eliminates directors elected by employees by right. There are six such firms and, as shown in Table 7, these do begin to significantly increase payouts after PEMP board representation ends. This is perhaps the single strongest and most clearcut evidence we can find indicating that it is employee board representation (PEMP) that depresses corporate payouts, and not simply the fact that a firm was privatized.

***** Insert Table 7 about here $* * * *$

\subsection{Other robustness checks of the PEMP-payout relationships}

This section describes the results of four additional robustness tests performed to verify that PEMP has a separate negative effect on corporate payouts, over and above the fact that a company was once state owned. The methodology and results of these tests are briefly discussed below, but in the interest of space no tabulations are presented — but these tables are available upon request. 
Since the binary privatized/not-privatized variable (PRIV) freezes a company's identity for all time, we include the number of years since privatization (NB_YEARS_PRIV) as an additional variable to measure how much a company in, say, 2006 may have evolved away from its industrial configuration and ownership structure in the year it was first privatized (say 1999). The NB_YEARS_PRIV variable has a significant negative sign in most of our payout regressions, but even with this new variable included PEMP remains significantly negative in almost all the payout analyses.

As a related test, we also exclude recently privatized companies--those divested less than 10 years previously - to examine only companies that have operated under private ownership long enough to cease being "privatized firms" in any meaningful sense. PEMP remains significantly negatively related to all five payout measures when recently privatized firms are excluded, and in fact the significance levels on the PEMP coefficients all increase substantially.

In order to tease out whether direct state control of a firm subsumes the separate effect of PEMP on payout, we include a dummy variable taking a value of 1 whenever the French state retains at least a blocking minority shareholding (33.33\% in French law) in a partially privatized company. In these companies the state is itself still wielding significant direct influence on firm policies, and thus PEMP should have little or no incremental explanatory power. Even in these cases, however, PEMP retains a significant negative influence on all five measures of payout.

Rather than treat all privatizations as a single explanatory variable, we break specific sales into five privatization waves based on the government in power at the time that a particular privatizing share sale was launched. This allows each of the five waves-representing sales by the Chirac (1986-88), Balladur (1993-95), Juppé (1995-97), Jospin (1997-2002), and Raffarin-Villepin (2002-2007) governments - to have a separate effect, as might be the case if different waves embodied different proscriptions for post-sale corporate governance. Our basic finding of a separate, significant, negative relationship between PEMP and all five measures of payout remains even after including separate privatization wave dummy variables.

\subsection{Further investigations of PEMPSHARE/value relationship}

We address the potential for reverse causality between PEMPSHARE and value in section 6.1 above. We use a 2SLS instrumental variables approach where PEMPSHARE is instrumented using the industry median PEMPSHARE. A strong positive relationship is verified between employee-shareholder

board representation and Tobin's Q, ROA computed using operating income, and ROA computed using net income.

Another potential concern is that employee representation could be strongly correlated with other governance mechanisms such as ownership concentration or the presence of independent directors. As a 
robustness test, we examine whether the presence of a major blockholder (the State) influences the relationship between PEMPSHARE and firm performance. Specifically, we include a dummy variable taking a value of 1 whenever the French state retains at least a blocking minority shareholding (33.33\% in French law) in a partially privatized company. In these companies the state is itself still wielding significant direct influence on firm policies. Even after controlling for this, however, PEMPSHARE remains positively and significantly related to valuation as measured by Tobin's Q and ROA. We also perform the same analysis with a dummy variable FAM taking a value of 1 when a founding family retains at least a blocking minority in a company, and the PEMPSHARE-value relationship remains significantly positive. Since the State and founding families are by far the two most important blockholders in large French companies, this suggests that modest levels of PEMPSHARE cause superior performance, even in presence of large shareholders as monitors. In the interest of space, we do not present a tabulation of these results, but these are available upon request.

As a final robustness check, we analyze the potential impact that having outsiders on a firm's board might have on firm performance and on PEMPSHARE's influence. Including such a POUTSIDERs variable for the fraction of the board represented by unaffiliated outsiders (not employees, managers, state, or founding family) in our regressions does not alter the significant, positive relationship between PEMPSHARE and valuation (Tobin's Q and ROA). Interestingly, POUTSIDERS has a significant negative impact on Tobin's Q and a significant positive impact on all measures of payout, while other ownership structure variables (family shareholdings, state ownership, proxies for different measures of employee shareholdings, and PEMP) all have the same relationship with performance. The results of this analysis are presented in Table 8.

\section{**** Insert Table 8 about here $* * * *$}

While the robustness tests described above do not absolutely disprove that there is reverse causality in the relationship between PEMPSHARE and firm value and performance, we believe that the weight of evidence implies that increasing employee-shareholder board representation leads to higher valuation and better performance, rather than the other way round.

\subsection{Generalizability of our results}

Clearly, the French employee ownership regime examined in this study is unique, and thus we cannot directly prove that our results are generalizeable to corporate governance settings in other countries. On the other hand, we believe our results are in fact generalizeable, at least to other advanced economies, for several reasons. First, the French companies that form our core sample of firms with both types of employee board representation are all large, highly visible companies that have operated in increasingly competitive global industries throughout our study period. There are comparable firms in all 
European and North American countries, so the industrial and financial forces impacting French companies (particularly privatized companies) will have direct analogs throughout the developed world.

A second, related factor supporting the generalizeability of our results is the shares of most of the large privatized French companies are cross-listed on U.S. and/or European stock markets. In fact, nonFrench institutional investors (mostly U.S. and U.K.) own over half of the stock of privatized French firms, as well as sizeable fractions of the largest non-privatized firms. Thus, these companies are operating in a truly global corporate governance market, and it is hard to imagine that these companies would retain shareholder-employee directors if these did not yield a true performance benefit.

Third, our findings of a positive impact of employee board representation on firm performance are generally consistent with the recent empirical evidence from Germany's codetermination system. This is especially true for the Fauver and Fuerst (2006) study, since they also show that employee representation does not penalize firm valuation - though we offer unique additional evidence of how different types of employee representation impact corporate payout policies.

Finally, our results are also consistent with the empirical evidence from other developed countries showing that increasing employee share ownership is associated with increasing firm value. In particular, empirical studies examining how the adoption of employee stock ownership (ESOP) by U.S. companies almost all document a positive relationship between ESOP adoption and improved firm performance. Although very few U.S. companies have employee board representatives on their boards - and those that do generally have directors imposed by unions - there is consistent empirical support for the proposition that rising voluntary employee share ownership increases value.

\section{Conclusions}

This study examines the impact of mandated employee board representation on corporate valuation and performance. French law mandates that employees of large publicly listed companies be allowed to elect directors for two reasons, by right of employment in formerly state-owned companies and when their shareholdings exceed three percent. These two rights have engendered substantial employee representation on the boards of over one-quarter of the largest French companies, and especially in privatized companies or firms that acquired a privatized firm that are the country's largest and most valuable. This provides a unique institutional setting in which to test whether and how employee representation impacts firm value, profitability, payout policies (cash dividends and repurchases), and board organization, complexity, and performance. We generate predictions based on received theory and test these predictions using a comprehensive sample of firms in the Société des Bourses Françaises (SBF) 120 Index from 1998 to 2008. 
We find that the presence of directors elected by employees by right significantly reduces payout ratios, increases overall staff costs, and increases board size, complexity, and meeting frequency — but does not significantly impact firm value or profitability. This result suggests there must be some significant benefit resulting from board representation by non-shareholder employee that offsets the unequivocal facts that these directors reduce cash payouts to shareholders, increase board complexity, and have no obvious community of interests with outside investors. We also document that directors elected by employee-shareholders significantly increase firm valuation and profitability but do not significantly impact corporate payout policy or board organization and performance. This suggests that the directors elected by employee-shareholders act like any other type of elected director, rather than specifically as employee representatives.

Since many corporate policies, especially those related to payout, may result endogenously rather than as a direct result of employee representation on corporate boards, we perform numerous robustness checks that verify the negative causal link between representation of employees by right and all types of corporate payouts. On balance, employee representation on corporate boards seems to be at least valueneutral, and may actually increase firm valuation and profitability when employee-shareholders elect company directors. 


\section{References}

Acharya, V.V., Myers, S.C., Rajan, R.G., 2011. The internal governance of firms. Journal of Finance, June, forthcoming.

Alchian, A.A., Demsetz, H., 1972. Production, information costs, and economic organization. American Economic Review 62, 777-795.

Allen, F., Carletti, E., Marquez, R., 2007. Stakeholder capitalism, corporate governance and firm value. Working paper, Wharton School.

Allen, F., Gale, D., 2002. A comparative theory of corporate governance. Working paper, Wharton School.

Atanassov, J., Han Kim, E., 2009. Labor and corporate governance: International evidence from restructuring decisions. Journal of Finance 64, 341-374.

Beatty, C.A., 1995. The cash flow and informational effects of employee stock ownership plans. Journal of Financial Economics 38, 211-240.

Becht, M., Böhmer, E., 1997. Transparency of ownership and control in Germany, in: The separation of ownership and control: A survey of 7 European countries. Preliminary report to the European Commission, Brussels, vol. 3 .

Berk, J.B., Stanton, R., Zechner, J., 2010. Human capital, bankruptcy and capital structure. Journal of Finance 65, 891-926.

Bertrand, M., Mullainathan, S., 2003. Enjoying the quiet life? Corporate governance and managerial preferences. Journal of Political Economy 111, 1043-1075.

Chen, H.J., Kacperczyk, M., Ortiz-Molina, H., 2011. Do non-financial stakeholders affect the pricing of risky debt? Evidence from unionized workers. Review of Finance, forthcoming.

Chang, S., 1990. Employee stock ownership plans and shareholders wealth: An empirical investigation. Financial Management 19, 48-58.

Chaplinsky, S., Niehaus, G., 1990. The tax and distributional effects of leveraged ESOPs. Financial Management 19, 29-38.

Claessens, S., Ueda, K., 2008. Banks and labor as stakeholders: Impact on economic performance. Working paper, International Monetary Fund, Washington, DC.

Coles, J.L., Daniel, N.D., Naveen, L., 2008. Boards: does one size fit all? Journal of Financial Economics 87, 329356.

Cronqvist, H., Heyman, F., Nilsson, M., Svaleryd, H., Vlachos, J., 2009. Do entrenched managers pay their workers more? Journal of Finance 64, 309-339.

DeAngelo, H., DeAngelo, L., 1991. Union negotiations and corporate policy: A study of labor concessions in the domestic steel industry during the 1980s. Journal of Financial Economics 30, 3-43.

Denis, D., McConnell, J., 2003. International corporate governance. Journal of Financial and Quantitative Analysis 38, $1-36$.

Ebbinghaus, B., Visser, J., 2000. Trade unions in Western Europe since 1945, Macmillan, London.

Faccio, M., Lang, L.H.P., Young, L., 2001. Dividends and expropriation. American Economic Review 91, 54-78. 
Faleye, O., Mehrotra, V., Morck, R., 2006. When labor has a voice in corporate governance. Journal of Financial and Quantitative Analysis 41, 489-510.

Fama, E.F., 1980. Agency problems and the theory of the firm. Journal of Political Economy 88, 288-307.

Fama, E.F., Jensen, M.C., 1983a. Separation of ownership and control. Journal of Law and Economics 26, 301-326.

Fama, E.F., Jensen, M.C., 1983b. Agency problems and residual claims. Journal of Law and Economics 26, 327-350.

Faria, H.J., Trahan, E., Rogers, R.C., 1993. ESOPs in public companies: Firm characteristics, shareholder wealth and impact on performance. Journal of Employee Ownership Law and Finance 5, 75-92.

Fauver, L., Fuerst, M.E., 2006. Does good governance include employee representation? Evidence from German corporate boards. Journal of Financial Economics 82, 673-710.

Franks, J., Mayer, C., 2001. Ownership and control of German corporations. Review of Financial Studies 14, 943-977.

Freeman, R.B., Lazear, E.P., 1995. An economic analysis of works councils, in: Roger, J., Streeck, W. (Eds.), Works councils: Consultation, representation and cooperation in industrial relations. University of Chicago Press, Chicago, pp. 27-52.

Furubotn, E., Wiggins, S., 1984. Plant closing, worker reallocation costs and efficiency gains to labor representation on boards of directors. Journal of Institutional and Theoretical Economics 140, 176-192.

Galai, D., Wiener, Z., 2008. Stakeholders and the composition of the voting rights of the board of directors. Journal of Corporate Finance 14, 107-117.

Gillette, A.B., Noe, T.H., Rebello, M.J., 2008. Board structures around the world: An experimental investigation. Review of Finance 12, 93-140.

Gordon, L.A., Pound, J., 1990. ESOPs and corporate control. Journal of Financial Economics 27, 525-555.

Gorton, G., Schmid, F.A., 2000. Universal banking and the performance of German firms. Journal of Financial Economics 58, 29-80.

Gorton, G., Schmid, F.A., 2004. Capital, labor, and the firm: A study of German codetermination. Journal of the European Economic Association 2, 863-905.

Greene, W.H., 2003. Econometric analysis, fifth ed. Prentice Hall, Upper Saddle River, NJ.

Hermalin, B.E., Weisbach, M.S., 1998. Endogenously chosen boards of directors and their monitoring of the CEO. American Economic Review 88, 96-118.

Himmelberg, C.P., Hubbard, R.G., Palia, D., 1999. Understanding the determinants of managerial ownership and the link between ownership and performance. Journal of Financial Economics 53, 353-384.

Jensen, M.C., 1986. Agency costs of free cash flow, corporate finance and takeovers. American Economic Review 76, 323-329.

Jensen, M.C., Meckling, W.H., 1976. Theory of the firm: Managerial behavior, agency costs and ownership structure. Journal of Financial Economics 3, 303-360.

Jensen, M.C., Meckling, W.H., 1979. Rights and production functions: An application to labor-managed firms and codetermination. Journal of Business 52, 469-506.

Jensen, M.C., Ruback, R.S., 1983. The market for corporate control: The scientific evidence. Journal of Financial Economics 11, 5-50. 
Kim, E.H., Ouimet, P., 2009. Employee capitalism or corporate socialism? Broad-based employee stock ownership. Working paper, Center for Economic Studies, U.S. Census Bureau.

La Porta, R., Lopez-De-Silanes, F., Shleifer, A., Vishny, R.W., 2000. Agency problems and dividend policies around the world. Journal of Finance 55, 1-33.

Lee, Y.-T., Liu, Y.-J., Zhu, N., 2008. The costs of owning employer stocks: Lessons from Taiwan. Journal of Financial and Quantitative Analysis 43, 717-740.

Levine, David I., and Laura D. Tyson, 1990. Participation, productivity and the firm's environment, in: Blinder, A. (Ed.), Paying for productivity: A look at the evidence. Brookings Institution, Washington, DC, pp. 183-237.

Linck, J.S., Netter, J.M., Yang, T., 2008. The determinants of board structure. Journal of Financial Economics 87, 308-328.

Pagano, M., Volpin, P., 2005. Managers, workers, and corporate control. Journal of Finance 60, 841-868.

Raheja, C.G., 2005. Determinants of board size and composition: A theory of corporate boards. Journal of Financial and Quantitative Analysis 40, 283-306.

Roe, M.J., 1998. German co-determination and German securities markets, in: Hopt, K.J., Kanda, H., Roe, M.J., Wymeersch, E., Prigge, S. (Eds.), Comparative corporate governance, state of the art and emerging research. Oxford University Press, Oxford, pp. 369-372.

Scholes, M.S., Wolfson, M.A., 1990. The effects of changes in tax laws on corporate reorganization activity. Journal of Business 63, S141-S164.

Shleifer, A., Vishny, R.W., 1997. A survey of corporate governance. Journal of Finance 52, 737-783.

Skinner, D., 2008. The evolving relation between earnings, dividends, and stock repurchases. Journal of Financial Economics 87, 582-609.

Stulz, R.M., 1988. Managerial control of voting rights. Journal of Financial Economics 20, 25-54.

Tirole, J., 2001. Corporate governance, Econometrica 69, 1-35.

Vafeas, N., 1999. Board meeting frequency and firm performance. Journal of Financial Economics 53, 113-142.

Von Eije, H., Megginson, W.L., 2008. Dividends and share repurchases in the European Union. Journal of Financial Economics 89, 347-374.

White, H., 1980. A heteroscedasticity-consistent covariance matrix estimator and a direct test for heteroscedasticity. Econometrica 48, 817-838. 
Figure 1 - Board structure trends: 1998-2008

The sample consists of all the SBF 120 Index firms over the period 1998-2008. Panel A reports the percent of firms with employee directors (directors elected from among the employees or the employee-shareholders). Panel B reports the percent of employee directors (directors elected from among the employees or the employee-shareholders) on boards of firms with employee representation. DEMPLOYEES is a dummy variable equal to one if the firm has employee directors on the board, and zero otherwise. $D E M P$ is a dummy variable equal to one if the firm has directors elected from among the employees on the board, and zero otherwise. DEMPSHARE is a dummy variable equal to one if the firm has directors elected from among the employee-shareholders on the board, and zero otherwise. PEMPLOYEES is the fraction of directors elected from among the employee directors on the board. PEMP is the fraction of directors elected from among the employees on the board. PEMPSHARE is the fraction of directors elected from among the employee-shareholders on the board.
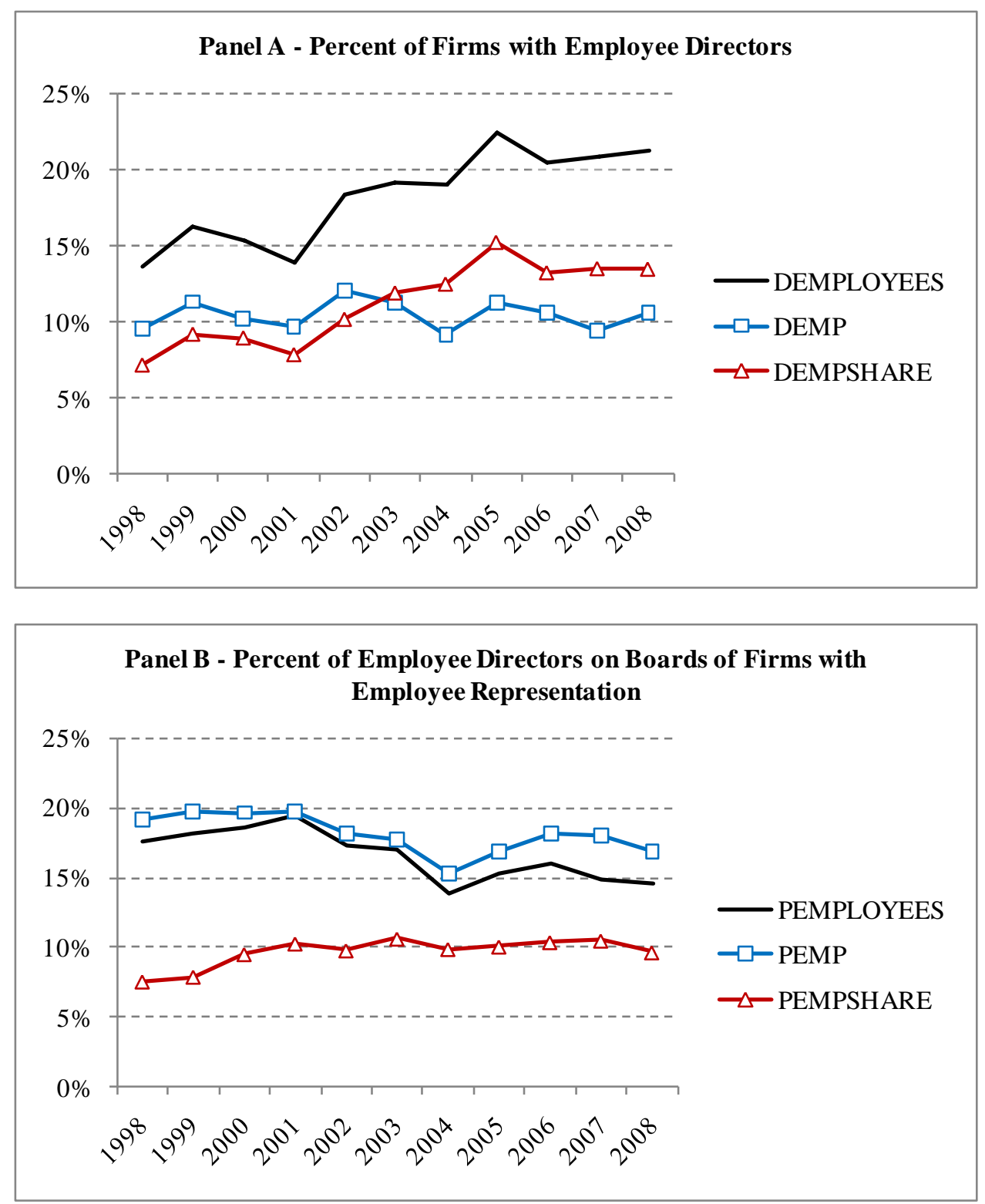
Table 1 - Composition of the sample by industry (one-digit SIC code)

This table reports the composition of the sample by industry - one-digit SIC code. The sample consists of all the SBF 120 Index firms over the period $1998-2008$.

\begin{tabular}{|c|c|c|c|c|c|c|c|c|c|c|c|c|}
\hline Industries & 1998 & 1999 & 2000 & 2001 & 2002 & 2003 & 2004 & 2005 & 2006 & 2007 & 2008 & Total \\
\hline Agriculture, mining, construction & $\begin{array}{c}11 \\
8.80 \% \\
\end{array}$ & $\begin{array}{c}11 \\
7.80 \% \\
\end{array}$ & $\begin{array}{c}10 \\
6.41 \% \\
\end{array}$ & $\begin{array}{c}10 \\
6.06 \% \\
\end{array}$ & $\begin{array}{c}8 \\
5.10 \% \\
\end{array}$ & $\begin{array}{c}8 \\
5.30 \% \\
\end{array}$ & $\begin{array}{c}8 \\
5.26 \% \\
\end{array}$ & $\begin{array}{c}9 \\
5.96 \% \\
\end{array}$ & $\begin{array}{c}9 \\
5.96 \% \\
\end{array}$ & $\begin{array}{c}9 \\
6.08 \% \\
\end{array}$ & $\begin{array}{c}9 \\
6.38 \% \\
\end{array}$ & $\begin{array}{c}102 \\
6.23 \% \\
\end{array}$ \\
\hline Manufacturing & $\begin{array}{c}50 \\
40.00 \% \\
\end{array}$ & $\begin{array}{c}54 \\
38.30 \% \\
\end{array}$ & $\begin{array}{c}55 \\
35.26 \% \\
\end{array}$ & $\begin{array}{c}57 \\
34.55 \% \\
\end{array}$ & $\begin{array}{c}57 \\
36.31 \% \\
\end{array}$ & $\begin{array}{c}54 \\
35.76 \% \\
\end{array}$ & $\begin{array}{c}54 \\
35.53 \% \\
\end{array}$ & $\begin{array}{c}53 \\
35.10 \% \\
\end{array}$ & $\begin{array}{c}56 \\
37.09 \% \\
\end{array}$ & $\begin{array}{c}56 \\
37.84 \% \\
\end{array}$ & $\begin{array}{c}53 \\
37.59 \% \\
\end{array}$ & $\begin{array}{c}599 \\
36.57 \% \\
\end{array}$ \\
\hline $\begin{array}{l}\text { Transportation, communications, } \\
\text { utilities }\end{array}$ & $\begin{array}{c}11 \\
8.80 \%\end{array}$ & $\begin{array}{c}13 \\
9.22 \%\end{array}$ & $\begin{array}{c}19 \\
12.18 \%\end{array}$ & $\begin{array}{c}22 \\
13.33 \%\end{array}$ & $\begin{array}{c}23 \\
14.65 \%\end{array}$ & $\begin{array}{c}23 \\
15.23 \%\end{array}$ & $\begin{array}{c}24 \\
15.79 \%\end{array}$ & $\begin{array}{c}25 \\
16.56 \%\end{array}$ & $\begin{array}{c}26 \\
17.22 \%\end{array}$ & $\begin{array}{c}24 \\
16.22 \%\end{array}$ & $\begin{array}{c}21 \\
14.89 \%\end{array}$ & $\begin{array}{c}231 \\
14.10 \%\end{array}$ \\
\hline Wholesale and retail trade & $\begin{array}{c}14 \\
11.20 \%\end{array}$ & $\begin{array}{c}15 \\
10.64 \%\end{array}$ & $\begin{array}{c}19 \\
12.18 \%\end{array}$ & $\begin{array}{c}22 \\
13.33 \%\end{array}$ & $\begin{array}{c}18 \\
11.46 \%\end{array}$ & $\begin{array}{c}17 \\
11.26 \%\end{array}$ & $\begin{array}{c}17 \\
11.18 \%\end{array}$ & $\begin{array}{c}15 \\
9.93 \% \\
\end{array}$ & $\begin{array}{c}13 \\
8.61 \% \\
\end{array}$ & $\begin{array}{c}13 \\
8.78 \% \\
\end{array}$ & $\begin{array}{c}12 \\
8.51 \% \\
\end{array}$ & $\begin{array}{c}175 \\
10.68 \%\end{array}$ \\
\hline Finance, insurance, real estate & $\begin{array}{c}17 \\
13.60 \% \\
\end{array}$ & $\begin{array}{c}23 \\
16.31 \% \\
\end{array}$ & $\begin{array}{c}23 \\
14.74 \% \\
\end{array}$ & $\begin{array}{c}23 \\
13.94 \% \\
\end{array}$ & $\begin{array}{c}22 \\
14.01 \% \\
\end{array}$ & $\begin{array}{c}20 \\
13.25 \% \\
\end{array}$ & $\begin{array}{c}20 \\
13.16 \% \\
\end{array}$ & $\begin{array}{c}20 \\
13.25 \% \\
\end{array}$ & $\begin{array}{c}20 \\
13.25 \% \\
\end{array}$ & $\begin{array}{c}19 \\
12.84 \% \\
\end{array}$ & $\begin{array}{c}19 \\
13.48 \% \\
\end{array}$ & $\begin{array}{c}226 \\
13.80 \% \\
\end{array}$ \\
\hline Business and personal services & $\begin{array}{c}22 \\
17.60 \% \\
\end{array}$ & $\begin{array}{c}25 \\
17.73 \% \\
\end{array}$ & $\begin{array}{c}30 \\
19.23 \% \\
\end{array}$ & $\begin{array}{c}31 \\
18.79 \% \\
\end{array}$ & $\begin{array}{c}29 \\
18.47 \% \\
\end{array}$ & $\begin{array}{c}29 \\
19.21 \% \\
\end{array}$ & $\begin{array}{c}29 \\
19.08 \% \\
\end{array}$ & $\begin{array}{c}29 \\
19.21 \% \\
\end{array}$ & $\begin{array}{c}27 \\
17.88 \% \\
\end{array}$ & $\begin{array}{c}27 \\
18.24 \% \\
\end{array}$ & $\begin{array}{c}27 \\
19.15 \% \\
\end{array}$ & $\begin{array}{c}305 \\
18.62 \% \\
\end{array}$ \\
\hline $\begin{array}{l}\text { Total } \\
\% \text { of total }\end{array}$ & $\begin{array}{c}125 \\
7.63 \% \\
\end{array}$ & $\begin{array}{c}141 \\
8.61 \% \\
\end{array}$ & $\begin{array}{c}156 \\
9.52 \% \\
\end{array}$ & $\begin{array}{c}165 \\
10.07 \% \\
\end{array}$ & $\begin{array}{c}157 \\
9.58 \% \\
\end{array}$ & $\begin{array}{c}151 \\
9.22 \% \\
\end{array}$ & $\begin{array}{c}152 \\
9.28 \% \\
\end{array}$ & $\begin{array}{c}151 \\
9.22 \% \\
\end{array}$ & $\begin{array}{c}151 \\
9.22 \% \\
\end{array}$ & $\begin{array}{c}148 \\
9.04 \% \\
\end{array}$ & $\begin{array}{c}141 \\
8.61 \% \\
\end{array}$ & $\begin{array}{c}1,638 \\
100.00 \%\end{array}$ \\
\hline
\end{tabular}


Table 2 - Descriptive statistics of variables over the period 1998-2008

This table presents summary statistics on key firm, ownership and board variables and tests of differences in means (Student test) and medians (Wilcoxon test) between different types of firms. The sample consists of all the SBF 120 Index firms over the period 1998-2008. SIZE is the book value of total assets in euro millions. LEVERAGE is measured as total debt over total assets. TANGIBLE is the ratio of tangible assets to total assets. CAPEX is the ratio of capital expenditures to total assets. $R O A$ is the return on assets measured as operating income over total assets. QTOBIN is the Tobin's $\mathrm{Q}$ defined as the market value of equity at the end of the fiscal year plus the book value of assets minus the book value of equity, all divided by the book value of assets. MTB is the market-tobook ratio measured as the market value of equity at the end of the fiscal year plus the book value of total liabilities, all divided by the book value of total assets. GROWTH is the growth rate computed as percentage change in net sales between years $N-1$ and $N$. VOLAT is the standard deviation of the monthly stock returns over the fiscal year immediately preceding the proxy date. STAFFCOSTS represents wages paid to employees and officers of the company divided by the number of employees. PAYOUT is constructed as a ratio of total cash dividends paid to common and preferred shareholders to net income. DIV/CF is the ratio of total cash dividends paid to common and preferred shareholders to cash flow. YIELD is the ratio of total cash dividends paid to common and preferred shareholders to market capitalization. REP/NETINC is the ratio of share repurchase amounts to net income. $R E P / C F$ is the ratio of share repurchase amounts to cash flow. $R E P / M V$ is the ratio of share repurchase amounts to market capitalization. CREP/NETINC is the ratio of cash dividends paid to common and preferred shareholders and share repurchase amounts to net income. $C R E P / C F$ is the ratio of total cash dividends paid to common and preferred shareholders plus share repurchase amounts to cash flow. $C R E P / M V$ is the ratio of total cash dividends paid to common and preferred shareholders plus share repurchase amounts to market capitalization. CREATION is the firm age in years. BOARDSIZE is the number of directors on the board. PWOMEN is the fraction of women on the board. POUTSIDERS is the fraction of independent directors on the board, using the criteria presented by Viénot $(1995,1999)$ and Bouton (2002). MEETINGS is the annual number of board meetings (it excludes actions by written consent of the directors and telephonic meetings of the board). COMMITTEES is the total number of standing board committees. SUPERVISORY is a dummy variable equal to one if the firm has a dual structure (Conseil de surveillance and Directoire), and zero if the firm has a unique board of directors (Conseil d'administration). EO is the ratio of the number of shares of all classes held by the employees to total shares outstanding. FAM is the ratio of the number of shares of all classes held by the founding families to total shares outstanding. STATE is the ratio of the number of shares of all classes held by the French state to total shares outstanding. $\mathrm{N}$ is the number of non-missing observations in the sample. ***,**,* indicate coefficients significance level: $1 \%, 5 \%$ and $10 \%$ respectively. 
Table 2 - Continued

\begin{tabular}{|c|c|c|c|c|c|c|c|c|c|c|c|c|c|}
\hline \multirow[t]{2}{*}{ Variables } & \multirow[t]{2}{*}{$\mathbf{N}$} & \multicolumn{2}{|c|}{$\begin{array}{c}\text { Firms with employee } \\
\text { directors }\end{array}$} & \multicolumn{2}{|c|}{$\begin{array}{c}\text { Firms without employee } \\
\text { directors }\end{array}$} & \multicolumn{2}{|c|}{$\begin{array}{c}\text { Firms with directors } \\
\text { elected by right }\end{array}$} & \multicolumn{2}{|c|}{$\begin{array}{c}\text { Firms without directors } \\
\text { elected by right }\end{array}$} & \multicolumn{2}{|c|}{$\begin{array}{l}\text { Firms with directors elected } \\
\text { by employee-shareholders }\end{array}$} & \multicolumn{2}{|c|}{$\begin{array}{c}\text { Firms without directors elected } \\
\text { by employee-shareholders }\end{array}$} \\
\hline & & Mean & Median & Mean & Median & Mean & Median & Mean & Median & Mean & Median & Mean & Median \\
\hline SIZE & 1,638 & $136,000.00$ & $24,558.51$ & $14,133.76^{* * *}$ & $1,869.44 * * *$ & $190,000.00$ & $29,755.51$ & $17,792.81 * * *$ & $2,164.80 * * *$ & $60,598.32$ & $22,920.40$ & $30,812.94 * * *$ & $2,106.50 * * *$ \\
\hline LEVERAGE & 1,638 & 0.264 & 0.223 & 0.262 & 0.245 & 0.276 & 0.226 & 0.261 & 0.241 & 0.257 & 0.234 & 0.263 & 0.240 \\
\hline TANGIBLE & 1,638 & 0.179 & 0.110 & $0.253 * * *$ & $0.177 * * *$ & 0.173 & 0.094 & $0.248 * * *$ & $0.172 * * *$ & 0.180 & 0.113 & $0.248 * * *$ & $0.172 * * *$ \\
\hline CAPEX & 1,638 & 0.037 & 0.034 & 0.077 & $0.042 * * *$ & 0.035 & 0.028 & 0.074 & $0.042 * * *$ & 0.040 & 0.039 & 0.074 & $0.041 * *$ \\
\hline ROA & 1,638 & 0.047 & 0.029 & 0.047 & $0.055 * * *$ & 0.045 & 0.025 & 0.047 & $0.054 * * *$ & 0.044 & 0.035 & 0.047 & $0.054 * * *$ \\
\hline QTOBIN & 1,638 & 1.449 & 1.168 & $1.944 * *$ & $1.380 * * *$ & 1.499 & 1.107 & 1.897 & $1.360 * * *$ & 1.335 & 1.179 & $1.920 * *$ & $1.362 * * *$ \\
\hline MTB & 1,638 & 0.897 & 0.674 & $1.572 * * *$ & $1.042 * * *$ & 0.912 & 0.608 & $1.515 * *$ & $1.009 * * *$ & 0.811 & 0.701 & $1.531 * * *$ & $1.014 * * *$ \\
\hline GROWTH & 1,638 & 0.089 & 0.062 & 1.736 & $0.098 * * *$ & 0.078 & 0.046 & 1.614 & $0.095^{* * * *}$ & 0.078 & 0.061 & 1.621 & $0.096^{* * * *}$ \\
\hline VOLAT & 1,614 & 0.092 & 0.080 & $0.101 * *$ & $0.088^{* *}$ & 0.094 & 0.087 & 0.100 & 0.087 & 0.091 & 0.076 & $0.101 *$ & $0.088^{* *}$ \\
\hline STAFFCOSTS & 1,633 & 58.794 & 56.59 & $50.295^{* * *}$ & $43.985^{* * *}$ & 62.712 & 61.076 & $50.582 * * *$ & $44.563^{* * *}$ & 54.221 & 53.911 & 51.417 & $45.475^{* * * *}$ \\
\hline PAYOUT & 1,638 & 0.399 & 0.308 & 0.313 & $0.232 * * *$ & 0.411 & 0.313 & 0.318 & $0.238 * * *$ & 0.398 & 0.292 & 0.319 & $0.238^{* * *}$ \\
\hline DIV/CF & 1,638 & 0.233 & 0.148 & 0.191 & $0.133 * *$ & 0.273 & 0.150 & $0.190 *$ & $0.135^{* *}$ & 0.168 & 0.136 & 0.201 & 0.136 \\
\hline YIELD & 1,638 & 0.029 & 0.022 & $0.021 * * *$ & $0.015 * * *$ & 0.031 & 0.022 & $0.022 * * *$ & $0.016 * * *$ & 0.026 & 0.021 & 0.022 & $0.016^{* * *}$ \\
\hline REP/NETINC & 1,638 & 0.052 & 0.000 & 0.069 & 0.000 & 0.026 & 0.000 & 0.071 & 0.000 & 0.074 & 0.000 & 0.065 & $0.000 * *$ \\
\hline REP/CF & 1,638 & 0.035 & 0.000 & 0.056 & 0.000 & 0.025 & 0.000 & 0.056 & 0.000 & 0.041 & 0.000 & 0.054 & $0.000 * *$ \\
\hline REP/MV & 1,626 & 0.005 & 0.000 & 0.006 & $0.000 *$ & 0.003 & 0.000 & 0.006 & 0.000 & 0.006 & 0.000 & 0.006 & $0.000^{* * *}$ \\
\hline CREP/NETINC & 1,637 & 0.451 & 0.351 & 0.449 & $0.268 * * *$ & 0.438 & 0.354 & 0.451 & $0.276^{*}$ & 0.472 & 0.332 & 0.446 & 0.276 \\
\hline CREP/CF & 1,635 & 0.267 & 0.169 & 0.249 & 0.157 & 0.298 & 0.174 & 0.247 & 0.157 & 0.209 & 0.150 & 0.258 & 0.159 \\
\hline CREP/MV & 1,620 & 0.034 & 0.024 & $0.028 *$ & $0.017 * * *$ & 0.034 & 0.023 & 0.028 & $0.018 * * *$ & 0.033 & 0.023 & 0.028 & $0.018 * * *$ \\
\hline CREATION & 1,638 & 77.440 & 63.000 & $56.131 * * *$ & $39.000 * * *$ & 67.930 & 61.000 & $59.069 * *$ & $41.000 * * *$ & 85.201 & 72.500 & $56.840 * * *$ & $40.000 * * *$ \\
\hline BOARDSIZE & 1,638 & 15.203 & 15.000 & $9.783^{* * * *}$ & $9.000 * * *$ & 16.035 & 16.000 & $10.158^{* * * *}$ & $10.000 * * *$ & 14.728 & 15.000 & $10.275^{* * * *}$ & $10.000 * * *$ \\
\hline PWOMEN & 1,638 & 0.071 & 0.065 & 0.075 & $0.000 * * *$ & 0.080 & 0.067 & 0.073 & $0.000 * * *$ & 0.074 & 0.067 & 0.074 & $0.000 * * *$ \\
\hline POUTSIDERS & 1,119 & 0.422 & 0.429 & 0.436 & 0.429 & 0.355 & 0.333 & $0.443 * * *$ & $0.429 * * *$ & 0.456 & 0.462 & 0.430 & 0.429 \\
\hline MEETINGS & 1,352 & 7.930 & 7.000 & $7.053 * * *$ & $6.000 * * *$ & 8.329 & 8.000 & $7.085^{* * * *}$ & $6.000 * * *$ & 7.554 & 7.000 & 7.192 & $6.000 * * *$ \\
\hline COMMITTEES & 1,636 & 2.907 & 3.000 & $1.932 * * *$ & $2.000 * * *$ & 2.983 & 3.000 & $2.008 * * *$ & $2.000 * * *$ & 2.848 & 3.000 & $2.017 * * *$ & $2.000 * * *$ \\
\hline SUPERVISORY & 1,638 & 0.133 & 0.000 & $0.315^{* * * *}$ & $0.000 * * *$ & 0.064 & 0.000 & $0.307 * * *$ & $0.000 * * *$ & 0.158 & 0.000 & $0.298 * * *$ & $0.000 * * *$ \\
\hline $\mathrm{EO}$ & 1,638 & 5.010 & 3.500 & $1.177 * * *$ & $0.400 * * *$ & 3.454 & 3.105 & $1.695 * * *$ & $0.500 * * *$ & 6.232 & 4.090 & $1.329 * * *$ & $0.490 * * *$ \\
\hline FAM & 1,638 & 1.047 & 0.000 & $19.885^{* * *}$ & $8.080 * * *$ & 0.292 & 0.000 & $18.33 * * *$ & $4.100 * * *$ & 1.473 & 0.000 & $18.330 * * *$ & $3.230 * * *$ \\
\hline STATE & 1,638 & 15.206 & 1.870 & $1.673 * * *$ & $0.000 * * *$ & 19.418 & 2.480 & $2.360 * * *$ & $0.000 * * *$ & 13.259 & 3.050 & $2.998 * * *$ & $0.000 * * *$ \\
\hline
\end{tabular}


Table 3 - Employee directors and firm performance

The table presents results from regressing the Tobin's Q $(Q T O B I N)$ defined as the market value of equity at the end of the fiscal year plus the book value of assets minus the book value of equity, all divided by the book value of assets and the return on assets (ROA) constructed as the ratio of operating income (alternatively using net income) to total assets on various firm, ownership and board characteristics. We estimate these variables via Ordinary Least Squares regressions and firm fixed-effect regressions. The sample consists of all the SBF 120 Index firms over the period 1998-2008. As in La Porta, et al. (2000) and Faccio, et al. (2001), we exclude firms with negative net income, negative cash flows and with dividends exceeding net income, sales, or cash flow. LSIZE is the natural log of the book value of total assets. GROWTH is the growth rate computed as percentage change in net sales between years $N-1$ and $N$. CAPEX is the ratio of capital expenditures to total assets. TANGIBLE is the ratio of tangible assets to total assets. VOLAT is the standard deviation of the monthly stock returns over the fiscal year immediately preceding the proxy date. PEMP is the fraction of directors elected from among the employees on the board. PEMPSHARE is the fraction of directors elected from among the employee-shareholders on the board. $E O<3$ is a dummy variable equal to one if the ratio of the number of shares of all classes held by the employees to total shares outstanding is strictly positive and less than $3 \%$, and zero otherwise. EO $\geq 10$ is a dummy variable equal to one if the ratio of the number of shares of all classes held by the employees to total shares outstanding is higher than $10 \%$, and zero otherwise. FAM is the ratio of the number of shares of all classes held by the founding families to total shares outstanding. STATE is the ratio of the number of shares of all classes held by the French state to total shares outstanding. PRIV is a dummy variable that equals one when the firm was formerly state-owned. Industry dummies and year dummies are included. The table presents the coefficients and Heteroskedasticity-consistent (White, 1980) t-values and then the $\mathrm{R}^{2}$ and adjusted $\mathrm{R}^{2} . \mathrm{N}$ is the number of non-missing observations in the sample. $* * *, * *, *$ indicate coefficients significant at the $1 \%, 5 \%$ and $10 \%$ levels, respectively.

\begin{tabular}{|c|c|c|c|c|c|c|c|c|c|}
\hline \multirow{2}{*}{ Variables } & \multicolumn{3}{|c|}{ QTOBIN } & \multicolumn{3}{|c|}{ ROA (using operating income) } & \multicolumn{3}{|c|}{ ROA (using net income) } \\
\hline & OLS & OLS & $\begin{array}{l}\text { Firm fixed- } \\
\text { effects }\end{array}$ & OLS & OLS & $\begin{array}{c}\text { Firm fixed- } \\
\text { effects }\end{array}$ & OLS & OLS & $\begin{array}{l}\text { Firm fixed- } \\
\text { effects }\end{array}$ \\
\hline LSIZE & $\begin{array}{c}-0.1140 * * \\
(-5.507)\end{array}$ & $\begin{array}{c}-0.1207 * * * \\
(-5.644)\end{array}$ & $\begin{array}{c}-0.2353 * * * \\
(-6.110)\end{array}$ & $\begin{array}{c}-0.0102 * * * \\
(-9.322)\end{array}$ & $\begin{array}{c}-0.0105 * * * \\
(-9.565)\end{array}$ & $\begin{array}{c}-0.0107 * * * \\
(-5.604)\end{array}$ & $\begin{array}{c}-0.0080 * * * \\
(-11.267)\end{array}$ & $\begin{array}{c}-0.0083 * * * \\
(-10.957)\end{array}$ & $\begin{array}{c}-0.0072 * * * \\
(-6.800)\end{array}$ \\
\hline GROWTH & $\begin{array}{c}-0.0012 * * * \\
(-5.651)\end{array}$ & $\begin{array}{c}-0.0013 * * * \\
(-5.673)\end{array}$ & $\begin{array}{c}-0.0009 * * * \\
(-3.373)\end{array}$ & $\begin{array}{c}-0.0001 * * * \\
(-5.224) \\
\end{array}$ & $\begin{array}{c}-0.0001 * * * \\
(-4.876)\end{array}$ & $\begin{array}{l}-0.0001 \\
(-0.733)\end{array}$ & $\begin{array}{c}0.0001 * * * \\
(16.357)\end{array}$ & $\begin{array}{c}0.0001 * * * \\
(13.292)\end{array}$ & $\begin{array}{c}0.0001 * * * \\
(14.750)\end{array}$ \\
\hline CAPEX & $\begin{array}{c}2.3707 * * * \\
(2.877)\end{array}$ & $\begin{array}{c}2.3726^{* * *} \\
(2.888) \\
\end{array}$ & $\begin{array}{c}3.0050 * * * \\
(3.457)\end{array}$ & $\begin{array}{c}0.0963^{* * *} * \\
(2.750)\end{array}$ & $\begin{array}{c}0.0996 * * * \\
(2.841)\end{array}$ & $\begin{array}{c}0.0926 * * \\
(2.459)\end{array}$ & $\begin{array}{c}0.0610 * * \\
(2.515)\end{array}$ & $\begin{array}{c}0.0654 * * * \\
(2.665)\end{array}$ & $\begin{array}{c}0.0514 * * \\
(2.063)\end{array}$ \\
\hline TANGIBLE & $\begin{array}{c}-0.8532 * * * \\
(-5.937)\end{array}$ & $\begin{array}{c}-0.8727 * * * \\
(-5.991)\end{array}$ & $\begin{array}{c}-0.5962 * * * \\
(-2.961)\end{array}$ & $\begin{array}{c}-0.0283 * * * \\
(-3.155)\end{array}$ & $\begin{array}{c}-0.0322 * * * \\
(-3.666)\end{array}$ & $\begin{array}{l}-0.0206^{*} \\
(-1.733)\end{array}$ & $\begin{array}{c}-0.0148 * * \\
(-2.303)\end{array}$ & $\begin{array}{c}-0.0195 * * * \\
(-3.050)\end{array}$ & $\begin{array}{l}-0.0137^{*} \\
(-1.731)\end{array}$ \\
\hline VOLAT & $\begin{array}{c}3.7618^{* * * *} \\
(4.272) \\
\end{array}$ & $\begin{array}{c}3.6415^{* * *} \\
(4.116) \\
\end{array}$ & $\begin{array}{c}3.4528 * * * \\
(4.072) \\
\end{array}$ & $\begin{array}{l}-0.0230 \\
(-0.547) \\
\end{array}$ & $\begin{array}{l}-0.0305 \\
(-0.723) \\
\end{array}$ & $\begin{array}{l}-0.0380 \\
(-1.267) \\
\end{array}$ & $\begin{array}{l}-0.0083 \\
(-0.310) \\
\end{array}$ & $\begin{array}{l}-0.0161 \\
(-0.610) \\
\end{array}$ & $\begin{array}{l}-0.0296 \\
(-1.344) \\
\end{array}$ \\
\hline PEMP & $\begin{array}{l}0.5950 \\
(0.910) \\
\end{array}$ & $\begin{array}{l}-0.0502 \\
(-0.095) \\
\end{array}$ & $\begin{array}{c}1.9073^{* *} \\
(2.253) \\
\end{array}$ & $\begin{array}{l}0.0406 \\
(1.426) \\
\end{array}$ & $\begin{array}{l}-0.0185 \\
(-0.597) \\
\end{array}$ & $\begin{array}{c}0.0781 * \\
(1.813) \\
\end{array}$ & $\begin{array}{c}0.0963 * * \\
(2.561)\end{array}$ & $\begin{array}{l}0.0303 \\
(1.176) \\
\end{array}$ & $\begin{array}{c}0.0828 * \\
(1.695)\end{array}$ \\
\hline PEMPSHARE & $\begin{array}{c}2.5279 * * * \\
(3.019) \\
\end{array}$ & $\begin{array}{c}2.2605^{* * *} \\
(2.641) \\
\end{array}$ & $\begin{array}{c}2.1953 * * * \\
(2.734) \\
\end{array}$ & $\begin{array}{c}0.1376^{* * * *} \\
(3.455)\end{array}$ & $\begin{array}{c}0.1162 * * * \\
(3.038) \\
\end{array}$ & $\begin{array}{c}0.1720^{* * * *} \\
(3.184) \\
\end{array}$ & $\begin{array}{c}0.1012^{* * *} \\
(4.139) \\
\end{array}$ & $\begin{array}{c}0.0779 * * * \\
(3.165)\end{array}$ & $\begin{array}{c}0.0772 * * \\
(2.502)\end{array}$ \\
\hline $\mathrm{EO}<3$ & $\begin{array}{c}0.2175^{* * * *} \\
(3.161)\end{array}$ & $\begin{array}{c}0.2132 * * * \\
(3.238)\end{array}$ & $\begin{array}{c}0.1730 * * \\
(2.013) \\
\end{array}$ & $\begin{array}{l}0.0026 \\
(0.571)\end{array}$ & $\begin{array}{l}0.0008 \\
(0.179) \\
\end{array}$ & $\begin{array}{l}0.0040 \\
(0.870)\end{array}$ & $\begin{array}{c}0.0080^{* *} \\
(2.347)\end{array}$ & $\begin{array}{c}0.0057 * \\
(1.761)\end{array}$ & $\begin{array}{l}0.0029 \\
(0.691) \\
\end{array}$ \\
\hline $\mathrm{EO} \geq 10$ & $\begin{array}{c}-0.5678 * * * \\
(-4.158) \\
\end{array}$ & $\begin{array}{c}-0.5399 * * * \\
(-3.798) \\
\end{array}$ & $\begin{array}{c}-0.3892 * * * \\
(-3.048) \\
\end{array}$ & $\begin{array}{c}-0.0343 * * * \\
(-4.569) \\
\end{array}$ & $\begin{array}{c}-0.0346 * * * \\
(-4.832) \\
\end{array}$ & $\begin{array}{l}0.0008 \\
(0.073) \\
\end{array}$ & $\begin{array}{c}-0.0214 * * * \\
(-5.135) \\
\end{array}$ & $\begin{array}{c}-0.0223 * * * \\
(-5.394) \\
\end{array}$ & $\begin{array}{l}-0.0077 \\
(-1.490) \\
\end{array}$ \\
\hline FAM & $\begin{array}{c}0.0038 * * \\
(2.042)\end{array}$ & $\begin{array}{c}0.0042 * * \\
(2.197)\end{array}$ & $\begin{array}{l}0.0034 \\
(1.057) \\
\end{array}$ & $\begin{array}{c}0.0002 * * \\
(2.036)\end{array}$ & $\begin{array}{c}0.0002 * * \\
(2.083)\end{array}$ & $\begin{array}{l}0.0001 \\
(0.847) \\
\end{array}$ & $\begin{array}{c}0.0001 * * \\
(2.072)\end{array}$ & $\begin{array}{c}0.0001 * * \\
(2.200)\end{array}$ & $\begin{array}{l}0.0001 \\
(0.933) \\
\end{array}$ \\
\hline STATE & $\begin{array}{l}-0.0022 \\
(-0.725)\end{array}$ & & $\begin{array}{l}0.0026 \\
(0.682)\end{array}$ & $\begin{array}{c}-0.0004 * * * \\
(-2.964)\end{array}$ & & $\begin{array}{l}0.0001 \\
(0.121)\end{array}$ & $\begin{array}{c}-0.0005^{* * *} \\
(-4.132)\end{array}$ & & $\begin{array}{l}-0.0003^{*} \\
(-1.696)\end{array}$ \\
\hline PRIV & & $\begin{array}{l}0.1235 \\
(1.130) \\
\end{array}$ & & & $\begin{array}{l}0.0026 \\
(0.434) \\
\end{array}$ & & & $\begin{array}{l}0.0012 \\
(0.309)\end{array}$ & \\
\hline Industry Dummies & Yes & Yes & & Yes & Yes & & Yes & Yes & \\
\hline Year Dummies & Yes & Yes & & Yes & Yes & & Yes & Yes & \\
\hline Constant & $\begin{array}{c}2.4339 * * * \\
(6.503) \\
\end{array}$ & $\begin{array}{c}2.5366^{* * * *} \\
(6.623) \\
\end{array}$ & $\begin{array}{c}4.6917 \text { *** } \\
(7.420)\end{array}$ & $\begin{array}{c}0.2307 * * * \\
(11.126) \\
\end{array}$ & $\begin{array}{c}0.2367 * * * \\
(11.365) \\
\end{array}$ & $\begin{array}{c}0.2275^{* * * *} \\
(6.962) \\
\end{array}$ & $\begin{array}{c}0.1518^{* * * *} \\
(10.962)\end{array}$ & $\begin{array}{c}0.1577 * * * \\
(11.27)\end{array}$ & $\begin{array}{c}0.1584 * * * \\
(8.727) \\
\end{array}$ \\
\hline $\mathrm{R}^{2}$ & 0.24 & 0.24 & 0.16 & 0.24 & 0.24 & 0.14 & 0.25 & 0.24 & 0.25 \\
\hline Adjusted $\mathrm{R}^{2}$ & 0.22 & 0.22 & & 0.22 & 0.22 & & 0.23 & 0.22 & \\
\hline $\mathrm{N}$ & 1,167 & 1,167 & $1,167 / 186$ & 1,167 & 1,167 & $1,167 / 186$ & 1,167 & 1,167 & $1,167 / 186$ \\
\hline
\end{tabular}


Table 4 - Employee directors and dividend policy

The table presents results from regressing the ratio of total cash dividends paid to common and preferred shareholders to net income (PAYOUT), the ratio of share repurchase amounts to net income (REP/NETINC), and the ratio of cash dividends paid to common and preferred shareholders and share repurchase amounts to net income (CREP/NETINC), cash flow $(C R E P / C F)$ and market capitalization $(C R E P / M V)$ on various firm, ownership and board characteristics. We estimate these variables via Ordinary Least Squares regressions and firm fixed-effect regressions. The sample consists of all the SBF 120 Index firms over the period 1998-2008. As in La Porta, et al. (2000) and Faccio, et al. (2001), we exclude firms with negative net income, negative cash flows and with dividends exceeding net income, sales, or cash flow. LSIZE is the natural log of the book value of total assets. ROA is the return on assets measured as operating income over total assets. GROWTH is the growth rate computed as percentage change in net sales between years $N-1$ and $N$. CAPEX is the ratio of capital expenditures to total assets. $M T B$ is the market-to-book ratio measured as the market value of equity at the end of the fiscal year plus the book value of total liabilities, all divided by the book value of total assets. VOLAT is the standard deviation of the monthly stock returns over the fiscal year immediately preceding the proxy date. PEMP is the fraction of directors elected from among the employees on the board. PEMPSHARE is the fraction of directors elected from among the employee-shareholders on the board. $E O<3$ is a dummy variable equal to one if the ratio of the number of shares of all classes held by the employees to total shares outstanding is strictly positive and less than 3\%, and zero otherwise. $E O \geq 10$ is a dummy variable equal to one if the ratio of the number of shares of all classes held by the employees to total shares outstanding is higher than $10 \%$, and zero otherwise. FAM is the ratio of the number of shares of all classes held by the founding families to total shares outstanding. STATE is the ratio of the number of shares of all classes held by the French state to total shares outstanding. PRIV is a dummy variable that equals one when the firm was formerly state-owned. Industry dummies and year dummies are included. The table presents the coefficients and heteroskedasticityconsistent (White, 1980) $\mathrm{t}$-values and then the $\mathrm{R}^{2}$ and adjusted $\mathrm{R}^{2} . \mathrm{N}$ is the number of non-missing observations in the sample. ***, **, * indicate coefficients significant at the $1 \%, 5 \%$, and $10 \%$ significance levels, respectively. 
Table 4 - Continued

\begin{tabular}{|c|c|c|c|c|c|c|c|c|c|c|c|c|c|c|c|}
\hline \multirow{2}{*}{ Variables } & \multicolumn{3}{|c|}{ PAYOUT } & \multicolumn{3}{|c|}{ REP/NETINC } & \multicolumn{3}{|c|}{ CREP/NETINC } & \multicolumn{3}{|c|}{ CREP/CF } & \multicolumn{3}{|c|}{ CREP/MV } \\
\hline & OLS & OLS & $\begin{array}{c}\text { Firm fixed- } \\
\text { effects }\end{array}$ & OLS & OLS & $\begin{array}{c}\text { Firm fixed- } \\
\text { effects }\end{array}$ & OLS & OLS & $\begin{array}{c}\text { Firm fixed- } \\
\text { effects }\end{array}$ & OLS & OLS & $\begin{array}{c}\text { Firm fixed- } \\
\text { effects }\end{array}$ & OLS & OLS & \begin{tabular}{|c}
$\begin{array}{c}\text { Firm fixed- } \\
\text { effects }\end{array}$ \\
\end{tabular} \\
\hline LSIZE & $\begin{array}{c}0.0071 * \\
(1.695)\end{array}$ & $\begin{array}{c}0.0100 * * \\
(2.257)\end{array}$ & $\begin{array}{c}0.0134 * * \\
(2.125) \\
\end{array}$ & $\begin{array}{c}0.0143 * * * \\
(2.965)\end{array}$ & $\begin{array}{c}0.0170 * * * \\
(3.370)\end{array}$ & $\begin{array}{c}0.0167 * * * \\
(2.879) \\
\end{array}$ & $\begin{array}{c}0.0214 * * * \\
(3.328)\end{array}$ & $\begin{array}{c}0.0270^{* * * *} \\
(3.999)\end{array}$ & $\begin{array}{c}0.0317 * * * \\
(3.851) \\
\end{array}$ & $\begin{array}{l}-0.0024 \\
(-0.515)\end{array}$ & $\begin{array}{l}0.0011 \\
(0.214) \\
\end{array}$ & $\begin{array}{c}0.0175^{* * * *} \\
(2.933) \\
\end{array}$ & $\begin{array}{c}0.0016^{* * * *} \\
(3.032)\end{array}$ & $\begin{array}{c}0.0019 * * * \\
(3.610)\end{array}$ & $\begin{array}{c}0.0035 * * * \\
(5.676)\end{array}$ \\
\hline ROA & $\begin{array}{l}0.0175 \\
(0.124) \\
\end{array}$ & $\begin{array}{l}-0.0003 \\
(-0.002) \\
\end{array}$ & $\begin{array}{c}-0.4690^{* * *} \\
(-3.143) \\
\end{array}$ & $\begin{array}{l}0.2374 \\
(1.506) \\
\end{array}$ & $\begin{array}{l}0.2497 \\
(1.596) \\
\end{array}$ & $\begin{array}{c}0.3053 * * \\
(1.963) \\
\end{array}$ & $\begin{array}{l}0.2549 \\
(1.385) \\
\end{array}$ & $\begin{array}{l}0.2494 \\
(1.378) \\
\end{array}$ & $\begin{array}{l}-0.0415 \\
(-0.190) \\
\end{array}$ & $\begin{array}{l}0.7307 \\
(1.645) \\
\end{array}$ & $\begin{array}{c}0.7355^{*} \\
(1.675) \\
\end{array}$ & $\begin{array}{l}0.7125 \\
(1.393) \\
\end{array}$ & $\begin{array}{c}0.0738 * * * \\
(2.949) \\
\end{array}$ & $\begin{array}{c}0.0750 * * * \\
(3.041) \\
\end{array}$ & $\begin{array}{c}0.1023 * * * \\
(4.151) \\
\end{array}$ \\
\hline GROWTH & $\begin{array}{c}-0.0002 * * * \\
(-4.244) \\
\end{array}$ & $\begin{array}{c}-0.0001 * * * \\
(-2.708) \\
\end{array}$ & $\begin{array}{c}-0.0001^{* *} \\
(-2.165) \\
\end{array}$ & $\begin{array}{l}-0.0001 \\
(-0.788) \\
\end{array}$ & $\begin{array}{r}-0.0001 \\
(0.619) \\
\end{array}$ & $\begin{array}{l}-0.0001 \\
(-1.285) \\
\end{array}$ & $\begin{array}{c}-0.0002 * * * \\
(-3.394) \\
\end{array}$ & $\begin{array}{l}-0.0001 \\
(-1.404) \\
\end{array}$ & $\begin{array}{c}-0.0001 * * * \\
(-3.044) \\
\end{array}$ & $\begin{array}{c}0.0002 * * * \\
(4.750) \\
\end{array}$ & $\begin{array}{c}0.0003^{* * *} \\
(5.680) \\
\end{array}$ & $\begin{array}{l}0.0001 \\
(0.544) \\
\end{array}$ & $\begin{array}{c}0.0001 * * * \\
(8.078) \\
\end{array}$ & $\begin{array}{c}0.0001 * * * \\
(8.743) \\
\end{array}$ & $\begin{array}{c}0.0001^{* * * *} \\
(6.283) \\
\end{array}$ \\
\hline CAPEX & $\begin{array}{c}-0.3351 * * \\
(-2.472)\end{array}$ & $\begin{array}{c}-0.3146^{* *} \\
(-2.339) \\
\end{array}$ & $\begin{array}{l}0.0808 \\
(0.633) \\
\end{array}$ & $\begin{array}{c}-0.2447 * * \\
(-2.253)\end{array}$ & $\begin{array}{c}-0.2444 * * \\
(-2.255)\end{array}$ & $\begin{array}{c}-0.2902 * * \\
(-2.290)\end{array}$ & $\begin{array}{c}-0.5798 * * * \\
(-3.049) \\
\end{array}$ & $\begin{array}{c}-0.5590 * * * \\
(-2.972)\end{array}$ & $\begin{array}{l}-0.2497 \\
(-1.266)\end{array}$ & $\begin{array}{c}-0.6618^{* * *} * \\
(-4.409) \\
\end{array}$ & $\begin{array}{c}-0.6541 * * * \\
(-4.431)\end{array}$ & $\begin{array}{c}-0.3810^{* *} \\
(-2.263)\end{array}$ & $\begin{array}{c}-0.0372 * * * \\
(-3.222) \\
\end{array}$ & $\begin{array}{c}-0.0370 * * * \\
(-3.282) \\
\end{array}$ & $\begin{array}{l}-0.0210 \\
(-1.541)\end{array}$ \\
\hline MTB & $\begin{array}{l}0.0001 \\
(0.015) \\
\end{array}$ & $\begin{array}{l}0.0005 \\
(0.089) \\
\end{array}$ & $\begin{array}{l}-0.0001 \\
(-0.035) \\
\end{array}$ & $\begin{array}{l}0.0043 \\
(0.736) \\
\end{array}$ & $\begin{array}{l}0.0045 \\
(0.767) \\
\end{array}$ & $\begin{array}{l}-0.0007 \\
(-0.135) \\
\end{array}$ & $\begin{array}{r}0.0044 \\
(0.592) \\
\end{array}$ & $\begin{array}{l}0.0049 \\
(0.678) \\
\end{array}$ & $\begin{array}{l}-0.0010 \\
(-0.147) \\
\end{array}$ & $\begin{array}{r}-0.0042 \\
(-0.325) \\
\end{array}$ & $\begin{array}{l}-0.0039 \\
(-0.306) \\
\end{array}$ & $\begin{array}{l}-0.0120 \\
(-1.042) \\
\end{array}$ & $\begin{array}{c}-0.0037 * * * \\
(-4.431) \\
\end{array}$ & $\begin{array}{c}-0.0037 * * * \\
(-4.443) \\
\end{array}$ & $\begin{array}{c}-0.0056^{* * *} \\
(-5.695) \\
\end{array}$ \\
\hline VOLAT & $\begin{array}{c}-0.9553 * * * \\
(-6.593) \\
\end{array}$ & $\begin{array}{c}-0.9088^{* * * *} \\
(-6.278) \\
\end{array}$ & $\begin{array}{l}-0.1505 \\
(-1.166) \\
\end{array}$ & $\begin{array}{c}-0.3660 * * * \\
(-2.579) \\
\end{array}$ & $\begin{array}{c}-0.3285^{* *} \\
(-2.331) \\
\end{array}$ & $\begin{array}{c}-0.3898 * * \\
(-2.512) \\
\end{array}$ & $\begin{array}{c}-1.3213^{* * * *} \\
(-6.080) \\
\end{array}$ & $\begin{array}{c}-1.2373 * * * \\
(-5.745) \\
\end{array}$ & $\begin{array}{c}-0.6949 * * * \\
(-3.209) \\
\end{array}$ & $\begin{array}{c}-0.9372 * * * \\
(-5.211) \\
\end{array}$ & $\begin{array}{c}-0.8860 \text { *** } \\
(-4.920) \\
\end{array}$ & $\begin{array}{c}-0.4158 * * \\
(-2.452) \\
\end{array}$ & $\begin{array}{c}-0.0480 * * * \\
(-3.187) \\
\end{array}$ & $\begin{array}{c}-0.0437 * * * \\
(-2.904) \\
\end{array}$ & $\begin{array}{l}-0.0034 \\
(-0.174) \\
\end{array}$ \\
\hline PEMP & $\begin{array}{c}-0.3041^{* *} \\
(-2.241)\end{array}$ & $\begin{array}{l}0.0201 \\
(0.174) \\
\end{array}$ & $\begin{array}{l}-0.2427 \\
(-1.293) \\
\end{array}$ & $\begin{array}{c}-0.3960^{* * *} \\
(-3.616) \\
\end{array}$ & $\begin{array}{c}-0.3088^{* * * *} \\
(-3.168) \\
\end{array}$ & $\begin{array}{c}-0.3453^{* *} \\
(-2.545) \\
\end{array}$ & $\begin{array}{c}-0.7000 * * * \\
(-3.883)\end{array}$ & $\begin{array}{c}-0.2887 * \\
(-1.895) \\
\end{array}$ & $\begin{array}{c}-0.6090 * * * \\
(-2.681)\end{array}$ & $\begin{array}{c}-0.2427^{*} \\
(-1.798) \\
\end{array}$ & $\begin{array}{l}-0.0460 \\
(-0.462) \\
\end{array}$ & $\begin{array}{c}-0.3909 * * \\
(-2.465)\end{array}$ & $\begin{array}{c}-0.0344 * * \\
(-2.517) \\
\end{array}$ & $\begin{array}{c}-0.0232 * * \\
(-2.359) \\
\end{array}$ & $\begin{array}{c}-0.0496^{* * * *} \\
(-3.126) \\
\end{array}$ \\
\hline PEMPSHARE & $\begin{array}{l}0.0102 \\
(0.057) \\
\end{array}$ & $\begin{array}{l}0.1464 \\
(0.822) \\
\end{array}$ & $\begin{array}{l}0.1206 \\
(0.502) \\
\end{array}$ & $\begin{array}{c}-0.2418^{*} \\
(-1.707) \\
\end{array}$ & $\begin{array}{r}-0.1943 \\
(-1.354) \\
\end{array}$ & $\begin{array}{l}-0.1560 \\
(-0.864) \\
\end{array}$ & $\begin{array}{l}-0.2315 \\
(-0.959) \\
\end{array}$ & $\begin{array}{l}-0.0479 \\
(-0.198) \\
\end{array}$ & $\begin{array}{l}-0.1249 \\
(-0.421) \\
\end{array}$ & $\begin{array}{l}-0.0262 \\
(-0.118) \\
\end{array}$ & $\begin{array}{l}0.0664 \\
(0.301) \\
\end{array}$ & $\begin{array}{l}0.1577 \\
(0.541) \\
\end{array}$ & $\begin{array}{l}-0.0244 \\
(-1.283) \\
\end{array}$ & $\begin{array}{l}-0.0185 \\
(-0.945) \\
\end{array}$ & $\begin{array}{l}-0.0237 \\
(-0.990) \\
\end{array}$ \\
\hline $\mathrm{EO}<3$ & $\begin{array}{l}0.0248 \\
(1.483) \\
\end{array}$ & $\begin{array}{c}0.0289 * \\
(1.727) \\
\end{array}$ & $\begin{array}{l}0.0005 \\
(0.024) \\
\end{array}$ & $\begin{array}{l}-0.0152 \\
(-0.814) \\
\end{array}$ & $\begin{array}{l}-0.0227 \\
(-1.261) \\
\end{array}$ & $\begin{array}{l}0.0088 \\
(0.434) \\
\end{array}$ & $\begin{array}{l}0.0096 \\
(0.354) \\
\end{array}$ & $\begin{array}{l}0.0061 \\
(0.229) \\
\end{array}$ & $\begin{array}{l}0.0114 \\
(0.385) \\
\end{array}$ & $\begin{array}{l}0.0144 \\
(0.697) \\
\end{array}$ & $\begin{array}{l}0.0090 \\
(0.430) \\
\end{array}$ & $\begin{array}{l}-0.0005 \\
(-0.019) \\
\end{array}$ & $\begin{array}{c}-0.0036^{*} \\
(-1.784) \\
\end{array}$ & $\begin{array}{c}-0.0044 * * \\
(-2.240) \\
\end{array}$ & $\begin{array}{l}-0.0027 \\
(-1.002) \\
\end{array}$ \\
\hline $\mathrm{EO} \geq 10$ & $\begin{array}{l}-0.0475 \\
(-1.379) \\
\end{array}$ & $\begin{array}{c}-0.0594^{*} \\
(-1.751) \\
\end{array}$ & $\begin{array}{c}-0.1141^{* *} \\
(-2.559) \\
\end{array}$ & $\begin{array}{l}0.0036 \\
(0.066) \\
\end{array}$ & $\begin{array}{l}-0.0145 \\
(-0.271) \\
\end{array}$ & $\begin{array}{l}0.0695 \\
(0.673) \\
\end{array}$ & $\begin{array}{l}-0.0439 \\
(-0.665) \\
\end{array}$ & $\begin{array}{l}-0.0738 \\
(-1.145) \\
\end{array}$ & $\begin{array}{l}-0.0250 \\
(-0.223) \\
\end{array}$ & $\begin{array}{l}-0.0175 \\
(-0.502) \\
\end{array}$ & $\begin{array}{l}-0.0383 \\
(-1.140) \\
\end{array}$ & $\begin{array}{l}-0.0202 \\
(-0.340) \\
\end{array}$ & $\begin{array}{l}-0.0008 \\
(-0.166) \\
\end{array}$ & $\begin{array}{l}-0.0028 \\
(-0.601) \\
\end{array}$ & $\begin{array}{l}0.0018 \\
(0.257) \\
\end{array}$ \\
\hline FAM & $\begin{array}{c}-0.0007^{* *} \\
(-2.261) \\
\end{array}$ & $\begin{array}{c}-0.0009 * * * \\
(-2.842) \\
\end{array}$ & $\begin{array}{c}-0.0012^{* *} \\
(-2.565) \\
\end{array}$ & $\begin{array}{l}-0.0005 \\
(-1.245) \\
\end{array}$ & $\begin{array}{r}-0.0006 \\
(-1.588) \\
\end{array}$ & $\begin{array}{l}-0.0004 \\
(-0.751) \\
\end{array}$ & $\begin{array}{c}-0.0011 * * \\
(-2.205) \\
\end{array}$ & $\begin{array}{c}-0.0015 * * * \\
(-2.776) \\
\end{array}$ & $\begin{array}{c}-0.0014 * \\
(-1.903) \\
\end{array}$ & $\begin{array}{l}-0.0005 \\
(-1.324) \\
\end{array}$ & $\begin{array}{c}-0.0007^{*} \\
(-1.820) \\
\end{array}$ & $\begin{array}{l}-0.0005 \\
(-0.916) \\
\end{array}$ & $\begin{array}{l}-0.0001 \\
(-1.228) \\
\end{array}$ & $\begin{array}{c}-0.0001^{*} \\
(-1.654) \\
\end{array}$ & $\begin{array}{l}-0.0001 \\
(-0.959) \\
\end{array}$ \\
\hline STATE & $\begin{array}{c}0.0012 * \\
(1.726) \\
\end{array}$ & & $\begin{array}{l}0.0011 \\
(1.191) \\
\end{array}$ & $\begin{array}{r}-0.0007 \\
(-1.489) \\
\end{array}$ & & $\begin{array}{r}-0.0004 \\
(-0.719) \\
\end{array}$ & $\begin{array}{l}0.0006 \\
(0.638) \\
\end{array}$ & & $\begin{array}{l}0.0009 \\
(0.851) \\
\end{array}$ & $\begin{array}{l}-0.0002 \\
(-0.239) \\
\end{array}$ & & $\begin{array}{l}-0.0001 \\
(-0.024) \\
\end{array}$ & $\begin{array}{l}-0.0001 \\
(-1.021) \\
\end{array}$ & & $\begin{array}{l}-0.0001 \\
(-0.280) \\
\end{array}$ \\
\hline PRIV & & $\begin{array}{c}-0.0556^{* * * *} \\
(-2.760) \\
\end{array}$ & & & $\begin{array}{c}-0.0598 * * * \\
(-2.736) \\
\end{array}$ & & & $\begin{array}{c}-0.1153 * * * \\
(-3.776) \\
\end{array}$ & & & $\begin{array}{c}-0.0747 * * * \\
(-3.806) \\
\end{array}$ & & & $\begin{array}{c}-0.0068 * * * \\
(-3.467) \\
\end{array}$ & \\
\hline $\begin{array}{l}\text { Industry } \\
\text { Dummies } \\
\end{array}$ & Yes & Yes & & Yes & Yes & & Yes & Yes & & Yes & Yes & & Yes & Yes & \\
\hline Year Dummies & Yes & Yes & & Yes & Yes & & Yes & Yes & & Yes & Yes & & Yes & Yes & \\
\hline Constant & $\begin{array}{c}0.2700^{* * * *} \\
(3.232)\end{array}$ & $\begin{array}{c}0.2272 * * * \\
(2.646) \\
\end{array}$ & $\begin{array}{l}0.1653 \\
(1.477) \\
\end{array}$ & $\begin{array}{l}0.0276 \\
(0.257) \\
\end{array}$ & $\begin{array}{l}-0.0059 \\
(-0.054) \\
\end{array}$ & $\begin{array}{l}-0.1289 \\
(-1.258) \\
\end{array}$ & $\begin{array}{c}0.2976^{* *} \\
(2.120) \\
\end{array}$ & $\begin{array}{l}0.2213 \\
(1.551) \\
\end{array}$ & $\begin{array}{l}0.0164 \\
(0.110) \\
\end{array}$ & $\begin{array}{c}0.3866^{* * *} \\
(3.159) \\
\end{array}$ & $\begin{array}{c}0.3405^{* * *} \\
(2.738) \\
\end{array}$ & $\begin{array}{l}0.0084 \\
(0.076) \\
\end{array}$ & $\begin{array}{c}0.0361 \text { *** } \\
(2.988) \\
\end{array}$ & $\begin{array}{c}0.0322 * * * \\
(2.676) \\
\end{array}$ & $\begin{array}{c}-0.0218^{*} \\
(-1.868) \\
\end{array}$ \\
\hline $\mathrm{R}^{2}$ & 0.21 & 0.21 & 0.07 & 0.06 & 0.07 & 0.07 & 0.15 & 0.16 & 0.14 & 0.17 & 0.18 & 0.11 & 0.30 & 0.30 & 0.29 \\
\hline Adjusted $\mathrm{R}^{2}$ & 0.19 & 0.19 & & 0.04 & 0.05 & & 0.13 & 0.13 & & 0.15 & 0.16 & & 0.28 & 0.29 & \\
\hline $\mathrm{N}$ & 1,170 & 1,170 & $1,170 / 186$ & 1,170 & 1,170 & $1,170 / 186$ & 1,170 & 1,170 & $1,170 / 186$ & 1,170 & 1,170 & $1,170 / 186$ & 1,170 & 1,170 & $1,170 / 186$ \\
\hline
\end{tabular}


Table 5 - Board meeting frequency and employee directors

The table presents results from regressing the number of annual board meetings (MEETINGS) on various firm, ownership and board characteristics. We estimate the number of annual board meetings via Poisson regressions and firm fixed-effect regressions. The sample consists of all the SBF 120 Index firms over the period 1998-2008. LSIZE is the natural log of the book value of total assets. ROA is the return on assets measured as operating income over total assets. GROWTH is the growth rate computed as percentage change in net sales between years $N-1$ and $N$. VOLAT is the standard deviation of the monthly stock returns over the fiscal year immediately preceding the proxy date. SUPERVISORY is a dummy variable equal to one if the firm has a dual structure (Conseil de surveillance and Directoire), and zero if the firm has a unique board of directors (Conseil d'administration). BOARDSIZE is the natural log of the number of directors on the board. PEMP is the fraction of directors elected from among the employees on the board. PEMPSHARE is the fraction of directors elected from among the employee-shareholders on the board. $E O<3$ is a dummy variable equal to one if the ratio of the number of shares of all classes held by the employees to total shares outstanding is strictly positive and less than $3 \%$, and zero otherwise. EO $\geq 10$ is a dummy variable equal to one if the ratio of the number of shares of all classes held by the employees to total shares outstanding is higher than $10 \%$, and zero otherwise. FAM is the ratio of the number of shares of all classes held by the founding families to total shares outstanding. STATE is the ratio of the number of shares of all classes held by the French state to total shares outstanding. PRIV is a dummy variable that equals one when the firm was formerly state-owned. Industry dummies and year dummies are included. The table presents the coefficients and heteroskedasticityconsistent (White, 1980) t-values and then the $\mathrm{R}^{2}$ and adjusted $\mathrm{R}^{2} . \mathrm{N}$ is the number of non-missing observations in the sample. $* * * * *, *$ indicate coefficients significant at the $1 \%, 5 \%$, and $10 \%$ significance levels, respectively.

\begin{tabular}{|c|c|c|c|c|c|c|}
\hline \multirow[b]{2}{*}{ Variables } & \multicolumn{6}{|c|}{ MEETINGS } \\
\hline & POISSON & POISSON & $\begin{array}{c}\text { Firm fixed- } \\
\text { effects }\end{array}$ & POISSON & POISSON & $\begin{array}{c}\text { Firm fixed- } \\
\text { effects }\end{array}$ \\
\hline LSIZE & $\begin{array}{c}0.0280 * * * \\
(4.033) \\
\end{array}$ & $\begin{array}{c}0.0254 * * * \\
(3.482) \\
\end{array}$ & $\begin{array}{c}0.0340 * * * \\
(2.872) \\
\end{array}$ & $\begin{array}{c}0.0474 * * * \\
(5.633) \\
\end{array}$ & $\begin{array}{c}0.0461 * * * \\
(5.267) \\
\end{array}$ & $\begin{array}{c}0.0495 * * * \\
(3.725)\end{array}$ \\
\hline ROA & $\begin{array}{c}-0.3230 * * * \\
(-2.718) \\
\end{array}$ & $\begin{array}{c}-0.3290 * * * \\
(-2.774) \\
\end{array}$ & $\begin{array}{c}-0.4232 * * * \\
(-3.154) \\
\end{array}$ & $\begin{array}{c}-0.3170 \text { *** } \\
(-2.591) \\
\end{array}$ & $\begin{array}{c}-0.3225 * * * \\
(-2.639) \\
\end{array}$ & $\begin{array}{c}-0.4166^{* * * *} \\
(-3.163)\end{array}$ \\
\hline GROWTH & $\begin{array}{l}0.0127 \\
(1.567) \\
\end{array}$ & $\begin{array}{l}0.0124 \\
(1.502) \\
\end{array}$ & $\begin{array}{l}0.0091 \\
(0.887) \\
\end{array}$ & $\begin{array}{l}0.0129 \\
(1.521) \\
\end{array}$ & $\begin{array}{c}0.0138^{*} \\
(1.675) \\
\end{array}$ & $\begin{array}{l}0.0097 \\
(0.944) \\
\end{array}$ \\
\hline VOLAT & $\begin{array}{c}2.0808^{* * * *} \\
(7.560) \\
\end{array}$ & $\begin{array}{c}2.0569 * * * \\
(7.432) \\
\end{array}$ & $\begin{array}{c}0.8788 \text { *** } \\
(4.245) \\
\end{array}$ & $\begin{array}{c}1.8446^{* * * *} \\
(6.808)\end{array}$ & $\begin{array}{c}1.8409 * * * \\
(6.765) \\
\end{array}$ & $\begin{array}{c}0.8412 * * * \\
(4.071)\end{array}$ \\
\hline SUPERVISORY & & & & $\begin{array}{c}-0.1339 * * * \\
(-4.481)\end{array}$ & $\begin{array}{c}-0.1247 * * * \\
(-4.235)\end{array}$ & $\begin{array}{c}-0.0934 * * \\
(-2.454)\end{array}$ \\
\hline LBOARDSIZE & & & & $\begin{array}{c}-0.1747 * * * \\
(-4.276) \\
\end{array}$ & $\begin{array}{c}-0.1705^{* * *} * \\
(-4.220) \\
\end{array}$ & $\begin{array}{c}-0.1454 * * \\
(-2.337) \\
\end{array}$ \\
\hline PEMP & $\begin{array}{c}0.5777 * * * \\
(2.782)\end{array}$ & $\begin{array}{c}0.4534 * * \\
(2.370) \\
\end{array}$ & $\begin{array}{l}0.0912 \\
(0.258) \\
\end{array}$ & $\begin{array}{c}0.5098 * * \\
(2.543) \\
\end{array}$ & $\begin{array}{c}0.5509 * * * \\
(2.869) \\
\end{array}$ & $\begin{array}{l}0.1223 \\
(0.347) \\
\end{array}$ \\
\hline PEMPSHARE & $\begin{array}{l}0.0765 \\
(0.181) \\
\end{array}$ & $\begin{array}{l}-0.0304 \\
(-0.077)\end{array}$ & $\begin{array}{l}0.7583 \\
(1.488) \\
\end{array}$ & $\begin{array}{l}0.1044 \\
(0.254)\end{array}$ & $\begin{array}{l}0.0903 \\
(0.234) \\
\end{array}$ & $\begin{array}{l}0.7003 \\
(1.392) \\
\end{array}$ \\
\hline $\mathrm{EO}<3$ & $\begin{array}{l}-0.0031 \\
(-0.082) \\
\end{array}$ & $\begin{array}{l}0.0029 \\
(0.078) \\
\end{array}$ & $\begin{array}{l}0.0436 \\
(0.993) \\
\end{array}$ & $\begin{array}{l}-0.0019 \\
(-0.048) \\
\end{array}$ & $\begin{array}{l}0.0105 \\
(0.283) \\
\end{array}$ & $\begin{array}{l}0.0471 \\
(1.081) \\
\end{array}$ \\
\hline $\mathrm{EO} \geq 10$ & $\begin{array}{c}-0.1170 * * \\
(-2.140)\end{array}$ & $\begin{array}{l}-0.0951^{*} \\
(-1.748)\end{array}$ & $\begin{array}{l}-0.0134 \\
(-0.110) \\
\end{array}$ & $\begin{array}{c}-0.0879 * \\
(-1.679)\end{array}$ & $\begin{array}{l}-0.0679 \\
(-1.285) \\
\end{array}$ & $\begin{array}{l}0.0012 \\
(0.010) \\
\end{array}$ \\
\hline FAM & $\begin{array}{c}-0.0013^{*} \\
(-1.892)\end{array}$ & $\begin{array}{l}-0.0011 \\
(-1.573) \\
\end{array}$ & $\begin{array}{l}-0.0004 \\
(-0.420) \\
\end{array}$ & $\begin{array}{c}-0.0014 * * \\
(-2.039) \\
\end{array}$ & $\begin{array}{l}-0.0013 * \\
(-1.852)\end{array}$ & $\begin{array}{l}-0.0007 \\
(-0.712) \\
\end{array}$ \\
\hline STATE & $\begin{array}{l}0.0003 \\
(0.351)\end{array}$ & & $\begin{array}{l}0.0015 \\
(0.988)\end{array}$ & $\begin{array}{l}0.0012 \\
(1.351)\end{array}$ & & $\begin{array}{l}0.0018 \\
(1.164)\end{array}$ \\
\hline PRIV & & $\begin{array}{c}0.0576^{*} \\
(1.941)\end{array}$ & & & $\begin{array}{l}0.0381 \\
(1.276) \\
\end{array}$ & \\
\hline Industry Dummies & Yes & Yes & & Yes & Yes & \\
\hline Year Dummies & Yes & Yes & & Yes & Yes & \\
\hline $\mathrm{C}$ & $\begin{array}{c}1.4599 * * * \\
(9.64)\end{array}$ & $\begin{array}{c}1.4927 * * * \\
(9.743)\end{array}$ & $\begin{array}{c}1.3390 * * * \\
(6.859) \\
\end{array}$ & $\begin{array}{c}1.6132^{* * * *} \\
(10.667)\end{array}$ & $\begin{array}{c}1.6103 * * * \\
(10.623) \\
\end{array}$ & $\begin{array}{c}1.4807 * * * \\
(7.436)\end{array}$ \\
\hline $\mathrm{R}^{2}$ & 0.18 & 0.18 & 0.13 & 0.21 & 0.20 & 0.18 \\
\hline Adjusted R² & 0.17 & 0.17 & & 0.19 & 0.19 & \\
\hline $\mathrm{N}$ & 1,291 & 1,291 & $1,291 / 189$ & 1,291 & 1,291 & $1,291 / 189$ \\
\hline
\end{tabular}


Table 6 - Second stage analysis of valuation and payout

This table reports the second stage of a 2 SLS regression using the average fraction of directors elected from among the employees or the employee-shareholders as instruments for PEMP and PEMPSHARE, respectively. The dependent variables are the Tobin's $\mathrm{Q}(Q T O B I N)$ defined as the market value of equity at the end of the fiscal year plus the book value of assets minus the book value of equity, all divided by the book value of assets, the return on assets (ROA) constructed as the ratio of operating income (alternatively using net income) to total assets, the ratio of total cash dividends paid to common and preferred shareholders to net income (PAYOUT) the ratio of share repurchase amounts to net income (REP/NETINC), the ratio of cash dividends paid to common and preferred shareholders and share repurchase amounts to net income (CREP/NETINC), cash flow $(C R E P / C F)$ and market capitalization $(C R E P / M V)$ on various firm, ownership and board characteristics. The sample consists of all the SBF 120 Index firms over the period 1998-2008. As in La Porta, et al. (2000) and Faccio et al. (2001), we exclude firms with negative net income, negative cash flows and with dividends exceeding net income, sales, or cash flow. LSIZE is the natural $\log$ of the book value of total assets. ROA is the return on assets measured as operating income over total assets. GROWTH is the growth rate computed as percentage change in net sales between years $N-1$ and $N$. $C A P E X$ is the ratio of capital expenditures to total assets. MTB is the market-to-book ratio measured as the market value of equity at the end of the fiscal year plus the book value of total liabilities, all divided by the book value of total assets. VOLAT is the standard deviation of the monthly stock returns over the fiscal year immediately preceding the proxy date. TANGIBLE is the ratio of tangible assets to total assets. PEMP is the fraction of directors elected from among the employees on the board. PEMPSHARE is the fraction of directors elected from among the employee-shareholders on the board. $E O<3$ is a dummy variable equal to one if the ratio of the number of shares of all classes held by the employees to total shares outstanding is strictly positive and less than $3 \%$, and zero otherwise. $E O \geq 10$ is a dummy variable equal to one if the ratio of the number of shares of all classes held by the employees to total shares outstanding is higher than $10 \%$, and zero otherwise. FAM is the ratio of the number of shares of all classes held by the founding families to total shares outstanding. STATE is the ratio of the number of shares of all classes held by the French state to total shares outstanding. Industry dummies and year dummies are included. The table presents the coefficients and heteroskedasticity-consistent (White, 1980) t-values and then the $\mathrm{R}^{2}$ and adjusted $\mathrm{R}^{2} . \mathrm{N}$ is the number of non-missing observations in the sample. ***,**, * indicate coefficients significant at the $1 \%$, $5 \%$, and $10 \%$ levels, respectively. 
Table 6 - Continued

\begin{tabular}{|c|c|c|c|c|c|c|c|c|}
\hline Variables & QTOBIN & $\begin{array}{c}\text { ROA (using } \\
\text { operating } \\
\text { income) }\end{array}$ & $\begin{array}{l}\text { ROA (using } \\
\text { net income) }\end{array}$ & PAYOUT & REP/NETINC & CREP/NETINC & CREP/CF & CREP/MV \\
\hline LSIZE & $\begin{array}{c}-0.1316^{* * *} * \\
(-5.467)\end{array}$ & $\begin{array}{c}-0.0112 * * * \\
(-9.914)\end{array}$ & $\begin{array}{c}-0.0083^{* * *} * \\
(-10.928)\end{array}$ & $\begin{array}{c}0.0109 * * \\
(2.357)\end{array}$ & $\begin{array}{c}0.0166^{* * * *} \\
(3.161)\end{array}$ & $\begin{array}{c}0.0275^{* * * *} \\
(3.878)\end{array}$ & $\begin{array}{l}0.0019 \\
(0.378) \\
\end{array}$ & $\begin{array}{c}0.0019 * * * \\
(3.550)\end{array}$ \\
\hline ROA & & & & $\begin{array}{l}0.0121 \\
(0.088) \\
\end{array}$ & $\begin{array}{l}0.2308 \\
(1.430) \\
\end{array}$ & $\begin{array}{l}0.2430 \\
(1.329) \\
\end{array}$ & $\begin{array}{l}0.7333 \\
(1.634) \\
\end{array}$ & $\begin{array}{c}0.0716^{* * * *} \\
(2.816)\end{array}$ \\
\hline GROWTH & $\begin{array}{l}-0.0014 \\
(-1.057) \\
\end{array}$ & $\begin{array}{l}-0.0001 \\
(-1.147) \\
\end{array}$ & $\begin{array}{c}0.0001 * * \\
(2.378) \\
\end{array}$ & $\begin{array}{c}-0.0002 * * * \\
(-4.999) \\
\end{array}$ & $\begin{array}{l}-0.0001 \\
(-1.287) \\
\end{array}$ & $\begin{array}{c}-0.0003 * * * \\
(-4.197) \\
\end{array}$ & $\begin{array}{c}0.0001 \text { *** } \\
(3.467)\end{array}$ & $\begin{array}{c}0.0001 * * * \\
(6.198)\end{array}$ \\
\hline CAPEX & $\begin{array}{c}2.4086^{* * * *} \\
(2.983)\end{array}$ & $\begin{array}{c}0.0988^{* * *} * \\
(2.615) \\
\end{array}$ & $\begin{array}{c}0.0630 * * \\
(2.459) \\
\end{array}$ & $\begin{array}{c}-0.3408 * * * \\
(-2.588) \\
\end{array}$ & $\begin{array}{c}-0.2462 * * \\
(-2.250) \\
\end{array}$ & $\begin{array}{c}-0.5871 * * * \\
(-3.146) \\
\end{array}$ & $\begin{array}{c}-0.6681 * * * \\
(-4.528) \\
\end{array}$ & $\begin{array}{c}-0.0382 * * * \\
(-3.368) \\
\end{array}$ \\
\hline MTB & & & & $\begin{array}{r}-0.0002 \\
(-0.047) \\
\end{array}$ & $\begin{array}{l}0.0040 \\
(0.686) \\
\end{array}$ & $\begin{array}{l}0.0038 \\
(0.521) \\
\end{array}$ & $\begin{array}{l}-0.0044 \\
(-0.342) \\
\end{array}$ & $\begin{array}{c}-0.0038 * * * \\
(-4.553) \\
\end{array}$ \\
\hline VOLAT & $\begin{array}{c}3.2734 * * * \\
(3.860) \\
\end{array}$ & $\begin{array}{l}-0.0524 \\
(-1.320) \\
\end{array}$ & $\begin{array}{l}-0.0171 \\
(-0.634) \\
\end{array}$ & $\begin{array}{c}-0.9289 * * * \\
(-6.344) \\
\end{array}$ & $\begin{array}{c}-0.3527 * * \\
(-2.493) \\
\end{array}$ & $\begin{array}{c}-1.2817 * * * \\
(-5.942) \\
\end{array}$ & $\begin{array}{c}-0.8964 * * * \\
(-4.974) \\
\end{array}$ & $\begin{array}{c}-0.0474 * * * \\
(-3.091) \\
\end{array}$ \\
\hline TANGIBLE & $\begin{array}{c}-0.8833 * * * \\
(-4.136) \\
\end{array}$ & $\begin{array}{c}-0.0305^{* * *} \\
(-3.051) \\
\end{array}$ & $\begin{array}{c}-0.0166^{* *} \\
(-2.448) \\
\end{array}$ & & & & & \\
\hline PEMP & $\begin{array}{l}-4.9755 \\
(-1.377) \\
\end{array}$ & $\begin{array}{c}-0.3292 * \\
(-1.946) \\
\end{array}$ & $\begin{array}{l}0.0281 \\
(0.245)\end{array}$ & $\begin{array}{c}-2.8147 * * * \\
(-4.579) \\
\end{array}$ & $\begin{array}{c}-1.9915^{* *} \\
(-2.368)\end{array}$ & $\begin{array}{c}-4.8062 * * * \\
(-4.454) \\
\end{array}$ & $\begin{array}{c}-2.4786 * * * \\
(-3.637)\end{array}$ & $\begin{array}{c}-0.3520 * * * \\
(-5.091)\end{array}$ \\
\hline PEMPSHARE & $\begin{array}{c}46.8370 * * * \\
(3.675) \\
\end{array}$ & $\begin{array}{c}2.8800^{* * * *} \\
(4.827) \\
\end{array}$ & $\begin{array}{c}0.9781 * * \\
(2.420) \\
\end{array}$ & $\begin{array}{c}4.3845^{* *} \\
(2.005) \\
\end{array}$ & $\begin{array}{l}2.1757 \\
(0.705) \\
\end{array}$ & $\begin{array}{c}6.5602 * \\
(1.686) \\
\end{array}$ & $\begin{array}{l}2.8822 \\
(1.166) \\
\end{array}$ & $\begin{array}{c}0.6885^{* *} \\
(2.537) \\
\end{array}$ \\
\hline $\mathrm{EO}<3$ & $\begin{array}{c}0.8844 * * * \\
(4.134) \\
\end{array}$ & $\begin{array}{c}0.0435^{* * *} \\
(4.34) \\
\end{array}$ & $\begin{array}{c}0.0216^{* * * *} \\
(3.182) \\
\end{array}$ & $\begin{array}{l}0.0448 \\
(1.233) \\
\end{array}$ & $\begin{array}{l}-0.0064 \\
(-0.142) \\
\end{array}$ & $\begin{array}{l}0.0384 \\
(0.634) \\
\end{array}$ & $\begin{array}{l}0.0140 \\
(0.383) \\
\end{array}$ & $\begin{array}{l}0.0021 \\
(0.490) \\
\end{array}$ \\
\hline $\mathrm{EO} \geq 10$ & $\begin{array}{c}-3.3454 * * * \\
(-3.907)\end{array}$ & $\begin{array}{c}-0.2070 * * * \\
(-5.163)\end{array}$ & $\begin{array}{c}-0.0742 * * * \\
(-2.733)\end{array}$ & $\begin{array}{c}-0.3733^{* * *} \\
(-2.646)\end{array}$ & $\begin{array}{l}-0.1856 \\
(-1.046) \\
\end{array}$ & $\begin{array}{c}-0.5589 * * \\
(-2.405)\end{array}$ & $\begin{array}{l}-0.2479 \\
(-1.538) \\
\end{array}$ & $\begin{array}{c}-0.0520 * * * \\
(-3.233)\end{array}$ \\
\hline FAM & $\begin{array}{c}0.0039 * * \\
(2.311) \\
\end{array}$ & $\begin{array}{c}0.0002^{* *} \\
(2.331) \\
\end{array}$ & $\begin{array}{c}0.0001 * * \\
(2.395) \\
\end{array}$ & $\begin{array}{c}-0.0008^{* * *} \\
(-2.826) \\
\end{array}$ & $\begin{array}{l}-0.0006 \\
(-1.458) \\
\end{array}$ & $\begin{array}{c}-0.0014 * * * \\
(-2.663) \\
\end{array}$ & $\begin{array}{c}-0.0007^{*} \\
(-1.723) \\
\end{array}$ & $\begin{array}{l}-0.0001 \\
(-1.547) \\
\end{array}$ \\
\hline STATE & $\begin{array}{r}0.0058 \\
(0.737) \\
\end{array}$ & $\begin{array}{l}0.0002 \\
(0.434) \\
\end{array}$ & $\begin{array}{l}-0.0004 \\
(-1.516) \\
\end{array}$ & $\begin{array}{c}0.0063^{* * * *} \\
(4.705) \\
\end{array}$ & $\begin{array}{l}0.0025 \\
(1.599) \\
\end{array}$ & $\begin{array}{c}0.0088^{* * *} \\
(4.068) \\
\end{array}$ & $\begin{array}{c}0.0045^{* * *} \\
(3.131) \\
\end{array}$ & $\begin{array}{c}0.0006^{* * *} \\
(3.903) \\
\end{array}$ \\
\hline Industry dummies & Yes & Yes & Yes & Yes & Yes & Yes & Yes & Yes \\
\hline Year dummies & Yes & Yes & Yes & Yes & Yes & Yes & Yes & Yes \\
\hline Constant & $\begin{array}{c}1.5711 * * * \\
(3.066)\end{array}$ & $\begin{array}{c}0.1768 * * * \\
(7.369)\end{array}$ & $\begin{array}{c}0.1309 * * * \\
(8.058)\end{array}$ & $\begin{array}{c}0.1801 * \\
(1.915)\end{array}$ & $\begin{array}{l}-0.0119 \\
(-0.090) \\
\end{array}$ & $\begin{array}{l}0.1682 \\
(0.998) \\
\end{array}$ & $\begin{array}{c}0.3202^{* *} \\
(2.533) \\
\end{array}$ & $\begin{array}{c}0.0221 * \\
(1.675)\end{array}$ \\
\hline $\mathrm{R}^{2}$ & 0.24 & 0.25 & 0.25 & 0.22 & 0.07 & 0.16 & 0.18 & 0.31 \\
\hline Adjusted R² & 0.23 & 0.23 & 0.23 & 0.20 & 0.04 & 0.14 & 0.16 & 0.29 \\
\hline $\mathrm{N}$ & 1,167 & 1,167 & 1,167 & 1,170 & 1,170 & 1,170 & 1,170 & 1,170 \\
\hline
\end{tabular}




\section{Table 7 - Elimination of elected employee directors (PEMP) from the board}

This table presents results from regressing the ratio of total cash dividends paid to common and preferred shareholders to net income (PAYOUT), the ratio of share repurchase amounts to net income (REP/NETINC), the ratio of cash dividends paid to common and preferred shareholders and share repurchase amounts to net income (CREP/NETINC), cash flow (CREP/CF) and market capitalization (CREP/MV) on various firm, ownership and board characteristics. The sample consists of all the SBF 120 Index firms over the period 1999-2008 after excluding all non-privatized firms. As in La Porta, et al. (2000) and Faccio, et al. (2001), firms with negative net income, negative cash flow and firms whose dividends exceed sales are excluded. LSIZE is the natural log of the book value of total assets. ROA is the return on assets measured as operating income over total assets. GROWTH is the growth rate computed as percentage change in net sales between years $N-1$ and $N$. CAPEX is the ratio of capital expenditures to total assets. MTB is the market-to-book ratio measured as the market value of equity at the end of the fiscal year plus the book value of total liabilities, all divided by the book value of total assets. VOLAT is the standard deviation of the monthly stock returns over the fiscal year immediately preceding the proxy date. ELIMINATION is a dummy variable that takes the value of one if elected employee directors were eliminated from the board between years $N-1$ and $N$, and zero otherwise. PEMP is the fraction of directors elected from among the employees on the board. PEMPSHARE is the fraction of directors elected from among the employee-shareholders on the board. EO<3 is a dummy variable equal to one if the ratio of the number of shares of all classes held by the employees to total shares outstanding is strictly positive and less than $3 \%$, and zero otherwise. $E O \geq 10$ is a dummy variable equal to one if the ratio of the number of shares of all classes held by the employees to total shares outstanding is higher than $10 \%$, and zero otherwise. FAM is the ratio of the number of shares of all classes held by the founding families to total shares outstanding. STATE is the ratio of the number of shares of all classes held by the French state to total shares outstanding. Industry dummies and year dummies are included. The table presents the coefficients and heteroskedasticity-consistent (White, 1980) $t$-values and then the $\mathrm{R}^{2}$ and adjusted $\mathrm{R}^{2} . \mathrm{N}$ is the number of nonmissing observations in the sample. ${ }^{* *}, * *, *$ indicate coefficients significant at the $1 \%, 5 \%$, and $10 \%$ levels, respectively. 
Table 7 - Continued

\begin{tabular}{|c|c|c|c|c|c|}
\hline Variables & PAYOUT & REP/NETINC & CREP/NETINC & CREP/CF & CREP/MV \\
\hline LSIZE & $\begin{array}{l}-0.0009 \\
(-0.065) \\
\end{array}$ & $\begin{array}{c}0.0143 * * \\
(2.025) \\
\end{array}$ & $\begin{array}{r}0.0134 \\
(0.860) \\
\end{array}$ & $\begin{array}{l}-0.0062 \\
(-0.772) \\
\end{array}$ & $\begin{array}{c}0.0026 * * \\
(1.977) \\
\end{array}$ \\
\hline ROA & $\begin{array}{l}0.0289 \\
(0.066) \\
\end{array}$ & $\begin{array}{l}0.0800 \\
(0.344) \\
\end{array}$ & $\begin{array}{l}0.1089 \\
(0.211) \\
\end{array}$ & $\begin{array}{l}0.2198 \\
(0.691) \\
\end{array}$ & $\begin{array}{c}0.0758 * * \\
(2.264) \\
\end{array}$ \\
\hline GROWTH & $\begin{array}{c}-0.0002 * \\
(-1.855) \\
\end{array}$ & $\begin{array}{l}-0.0001 \\
(-1.182) \\
\end{array}$ & $\begin{array}{c}-0.0003 * * \\
(-2.099) \\
\end{array}$ & $\begin{array}{l}0.0001 \\
(1.381) \\
\end{array}$ & $\begin{array}{c}0.0001 * * * \\
(3.832) \\
\end{array}$ \\
\hline CAPEX & $\begin{array}{c}-1.1575 * * * \\
(-3.310) \\
\end{array}$ & $\begin{array}{l}-0.2019 \\
(-0.541) \\
\end{array}$ & $\begin{array}{c}-1.3594 * * \\
(-2.575) \\
\end{array}$ & $\begin{array}{c}-1.1435 * * * \\
(-3.786) \\
\end{array}$ & $\begin{array}{c}-0.1170 * \\
(-1.858) \\
\end{array}$ \\
\hline МТВ & $\begin{array}{l}-0.0163 \\
(-1.000) \\
\end{array}$ & $\begin{array}{l}0.0001 \\
(0.004) \\
\end{array}$ & $\begin{array}{l}-0.0162 \\
(-0.706) \\
\end{array}$ & $\begin{array}{l}-0.0032 \\
(-0.249) \\
\end{array}$ & $\begin{array}{c}-0.0041 * \\
(-1.901) \\
\end{array}$ \\
\hline VOLAT & $\begin{array}{l}-0.9079 * \\
(-1.942) \\
\end{array}$ & $\begin{array}{l}-0.1705 \\
(-0.892) \\
\end{array}$ & $\begin{array}{c}-1.0783 * * \\
(-2.030) \\
\end{array}$ & $\begin{array}{c}-0.8527 * * * \\
(-3.134) \\
\end{array}$ & $\begin{array}{c}-0.0583 * \\
(-1.780) \\
\end{array}$ \\
\hline ELIMINATION & $\begin{array}{l}0.1384 \\
(1.178) \\
\end{array}$ & $\begin{array}{l}0.0960 \\
(1.267) \\
\end{array}$ & $\begin{array}{c}0.2344 * * \\
(2.111)\end{array}$ & $\begin{array}{c}0.2262 * * * \\
(2.690) \\
\end{array}$ & $\begin{array}{l}0.0131 * \\
(1.724) \\
\end{array}$ \\
\hline PEMP & $\begin{array}{l}-0.1045 \\
(-0.570) \\
\end{array}$ & $\begin{array}{c}-0.3377 * * \\
(-2.350) \\
\end{array}$ & $\begin{array}{c}-0.4423^{*} \\
(-1.838) \\
\end{array}$ & $\begin{array}{l}-0.0064 \\
(-0.047) \\
\end{array}$ & $\begin{array}{l}-0.0110 \\
(-0.748) \\
\end{array}$ \\
\hline PEMPSHARE & $\begin{array}{l}-0.4639 \\
(-1.037) \\
\end{array}$ & $\begin{array}{c}-0.6555^{* *} \\
(-2.230) \\
\end{array}$ & $\begin{array}{c}-1.1195 * * \\
(-2.107) \\
\end{array}$ & $\begin{array}{l}-0.5282 \\
(-1.511) \\
\end{array}$ & $\begin{array}{l}-0.0397 \\
(-1.244) \\
\end{array}$ \\
\hline $\mathrm{EO}<3$ & $\begin{array}{l}-0.0118 \\
(-0.308)\end{array}$ & $\begin{array}{c}-0.0614 * \\
(-1.788)\end{array}$ & $\begin{array}{l}-0.0731 \\
(-1.418)\end{array}$ & $\begin{array}{c}-0.0741 * * \\
(-2.546)\end{array}$ & $\begin{array}{l}-0.0044 \\
(-1.536)\end{array}$ \\
\hline $\mathrm{EO} \geq 10$ & $\begin{array}{c}-0.1951 * * \\
(-2.505) \\
\end{array}$ & $\begin{array}{l}-0.0373 \\
(-0.963) \\
\end{array}$ & $\begin{array}{c}-0.2324 * * \\
(-2.550) \\
\end{array}$ & $\begin{array}{c}-0.2169 * * * \\
(-3.971) \\
\end{array}$ & $\begin{array}{l}-0.0067 \\
(-0.852) \\
\end{array}$ \\
\hline FAM & $\begin{array}{l}-0.0010 \\
(-0.605) \\
\end{array}$ & $\begin{array}{l}0.0007 \\
(0.364) \\
\end{array}$ & $\begin{array}{l}-0.0003 \\
(-0.109) \\
\end{array}$ & $\begin{array}{l}-0.0007 \\
(-0.450) \\
\end{array}$ & $\begin{array}{l}0.0006 \\
(0.832) \\
\end{array}$ \\
\hline STATE & $\begin{array}{l}0.0013 \\
(1.282)\end{array}$ & $\begin{array}{l}-0.0003 \\
(-0.677)\end{array}$ & $\begin{array}{l}0.0010 \\
(0.912)\end{array}$ & $\begin{array}{l}-0.0004 \\
(-0.552)\end{array}$ & $\begin{array}{l}-0.0001 \\
(-1.399)\end{array}$ \\
\hline Industry dummies & Yes & Yes & Yes & Yes & Yes \\
\hline Year dummies & Yes & Yes & Yes & Yes & Yes \\
\hline Constant & $\begin{array}{c}0.4540 * \\
(1.841) \\
\end{array}$ & $\begin{array}{l}-0.0729 \\
(-0.565) \\
\end{array}$ & $\begin{array}{l}0.3811 \\
(1.422) \\
\end{array}$ & $\begin{array}{c}0.4307 * * * \\
(2.989) \\
\end{array}$ & $\begin{array}{l}0.0007 \\
(0.037) \\
\end{array}$ \\
\hline $\mathrm{R}^{2}$ & 0.26 & 0.24 & 0.29 & 0.45 & 0.44 \\
\hline Adjusted R ${ }^{2}$ & 0.15 & 0.14 & 0.20 & 0.37 & 0.37 \\
\hline $\mathrm{N}$ & 229 & 229 & 229 & 229 & 229 \\
\hline
\end{tabular}


Table 8 - Fraction of outsiders

This table presents results from regressing the Tobin's Q ( QTOBIN) defined as the market value of equity at the end of the fiscal year plus the book value of assets minus the book value of equity, all divided by the book value of assets, the return on assets $(R O A)$ constructed as the ratio of operating income to total assets (alternatively using net income), the ratio of total cash dividends paid to common and preferred shareholders to net income (PAYOUT) the ratio of share repurchase amounts to net income (REP/NETINC), the ratio of cash dividends paid to common and preferred shareholders and share repurchase amounts to net income (CREP/NETINC), and the number of annual board meetings (MEETINGS) on various firm, ownership and board characteristics. We estimate these variables via Ordinary Least Squares regressions and Poisson regressions for the MEETINGS variable. The sample consists of all the SBF 120 Index firms over the period 1998-2008. As in La Porta, et al. (2000) and Faccio, et al. (2001), we exclude firms with negative net income, negative cash flows and with dividends exceeding net income, sales, or cash flow (except for the MEETINGS variable). LSIZE is the natural log of the book value of total assets. ROA is the return on assets measured as operating income over total assets. GROWTH is the growth rate computed as percentage change in net sales between years $N-1$ and $N$. CAPEX is the ratio of capital expenditures to total assets. $M T B$ is the market-to-book ratio measured as the market value of equity at the end of the fiscal year plus the book value of total liabilities, all divided by the book value of total assets. VOLAT is the standard deviation of the monthly stock returns over the fiscal year immediately preceding the proxy date. TANGIBLE is the ratio of tangible assets to total assets. $P E M P$ is the fraction of directors elected from among the employees on the board. PEMPSHARE is the fraction of directors elected from among the employee-shareholders on the board. POUTSIDERS is the fraction of independent directors on the board, using the criteria presented by Viénot $(1995,1999)$ and Bouton (2002). EO<3 is a dummy variable equal to one if the ratio of the number of shares of all classes held by the employees to total shares outstanding is strictly positive and less than $3 \%$, and zero otherwise. $E O \geq 10$ is a dummy variable equal to one if the ratio of the number of shares of all classes held by the employees to total shares outstanding is higher than $10 \%$, and zero otherwise. FAM is the ratio of the number of shares of all classes held by the founding families to total shares outstanding. STATE is the ratio of the number of shares of all classes held by the French state to total shares outstanding. Industry dummies and year dummies are included. The table presents the coefficients and heteroskedasticity-consistent (White, 1980) t-values and then the $\mathrm{R}^{2}$ and adjusted $\mathrm{R}^{2}$. $\mathrm{N}$ is the number of nonmissing observations in the sample. $* * *, * *, *$ indicate coefficients significant at the $1 \%, 5 \%$, and $10 \%$ levels, respectively. 
Table 8 - Continued

\begin{tabular}{|c|c|c|c|c|c|c|c|}
\hline Variables & QTOBIN & $\begin{array}{c}\text { ROA (using } \\
\text { operating } \\
\text { income) }\end{array}$ & $\begin{array}{l}\text { ROA (using } \\
\text { net income) }\end{array}$ & PAYOUT & REP/NETINC & CREP/NETINC & MEETINGS \\
\hline LSIZE & $\begin{array}{c}-0.0583 * * * \\
(-2.984)\end{array}$ & $\begin{array}{c}-0.0088^{* * * *} \\
(-7.350)\end{array}$ & $\begin{array}{c}-0.0066^{* * *} \\
(-7.474) \\
\end{array}$ & $\begin{array}{l}0.0066 \\
(1.253) \\
\end{array}$ & $\begin{array}{l}0.0047 \\
(0.768) \\
\end{array}$ & $\begin{array}{l}0.0113 \\
(1.351) \\
\end{array}$ & $\begin{array}{c}0.0280^{* * * *} \\
(3.516)\end{array}$ \\
\hline ROA & & & & $\begin{array}{l}-0.1828 \\
(-1.008) \\
\end{array}$ & $\begin{array}{l}0.0699 \\
(0.293) \\
\end{array}$ & $\begin{array}{l}-0.1128 \\
(-0.430) \\
\end{array}$ & $\begin{array}{c}-0.4093 * * * \\
(-2.749) \\
\end{array}$ \\
\hline GROWTH & $\begin{array}{l}0.0163 \\
(0.196) \\
\end{array}$ & $\begin{array}{c}0.0108^{* * *} \\
(2.122) \\
\end{array}$ & $\begin{array}{c}0.0079 * * \\
(2.085) \\
\end{array}$ & $\begin{array}{c}-0.0448 * * \\
(-2.350) \\
\end{array}$ & $\begin{array}{l}0.0546 \\
(0.998) \\
\end{array}$ & $\begin{array}{l}0.0098 \\
(0.144) \\
\end{array}$ & $\begin{array}{l}0.0104 \\
(1.105) \\
\end{array}$ \\
\hline CAPEX & $\begin{array}{c}4.0246^{* * *} \\
(5.267) \\
\end{array}$ & $\begin{array}{c}0.1731 * * * \\
(3.699) \\
\end{array}$ & $\begin{array}{c}0.0742^{* * *} \\
(2.142) \\
\end{array}$ & $\begin{array}{c}-0.4370 * * \\
(-2.224) \\
\end{array}$ & $\begin{array}{c}-0.5198 * * * \\
(-2.701) \\
\end{array}$ & $\begin{array}{c}-0.9568 * * * \\
(-3.131) \\
\end{array}$ & \\
\hline МТВ & & & & $\begin{array}{l}0.0129 \\
(1.487) \\
\end{array}$ & $\begin{array}{c}0.0296 * * \\
(2.055) \\
\end{array}$ & $\begin{array}{c}0.0425 * * \\
(2.407) \\
\end{array}$ & \\
\hline VOLAT & $\begin{array}{c}1.7830 * * \\
(2.323) \\
\end{array}$ & $\begin{array}{c}-0.0818^{*} \\
(-1.740) \\
\end{array}$ & $\begin{array}{l}-0.0270 \\
(-0.775) \\
\end{array}$ & $\begin{array}{c}-1.1292 * * * \\
(-5.478) \\
\end{array}$ & $\begin{array}{c}-0.6299 * * * \\
(-2.650) \\
\end{array}$ & $\begin{array}{c}-1.7591 * * * \\
(-5.244) \\
\end{array}$ & $\begin{array}{c}2.0634 * * * \\
(9.420) \\
\end{array}$ \\
\hline TANGIBLE & $\begin{array}{c}-0.6506 * * * \\
(-3.703) \\
\end{array}$ & $\begin{array}{c}-0.0232^{* *} \\
(-2.160) \\
\end{array}$ & $\begin{array}{l}-0.0042 \\
(-0.528) \\
\end{array}$ & & & & \\
\hline PEMP & $\begin{array}{l}-0.2086 \\
(-0.297)\end{array}$ & $\begin{array}{l}0.0072 \\
(0.167)\end{array}$ & $\begin{array}{c}0.1015^{* * * *} \\
(3.186)\end{array}$ & $\begin{array}{c}-0.3057 * \\
(-1.787)\end{array}$ & $\begin{array}{c}-0.3617 * * * \\
(-2.657) \\
\end{array}$ & $\begin{array}{c}-0.6674 * * * \\
(-2.991) \\
\end{array}$ & $\begin{array}{c}0.4076^{*} \\
(1.739) \\
\end{array}$ \\
\hline PEMPSHARE & $\begin{array}{c}3.0338 * * * \\
(3.313) \\
\end{array}$ & $\begin{array}{c}0.1469^{* * *} \\
(2.621) \\
\end{array}$ & $\begin{array}{c}0.1156^{* * *} \\
(2.787) \\
\end{array}$ & $\begin{array}{l}-0.1016 \\
(-0.498) \\
\end{array}$ & $\begin{array}{c}-0.3677 * * \\
(-2.129) \\
\end{array}$ & $\begin{array}{l}-0.4693 \\
(-1.598) \\
\end{array}$ & $\begin{array}{l}0.0478 \\
(0.129) \\
\end{array}$ \\
\hline POUTSIDERS & $\begin{array}{c}-0.4790 * * * \\
(-3.243) \\
\end{array}$ & $\begin{array}{l}-0.0122 \\
(-1.354) \\
\end{array}$ & $\begin{array}{l}-0.0084 \\
(-1.259) \\
\end{array}$ & $\begin{array}{c}0.0935 * * \\
(2.504) \\
\end{array}$ & $\begin{array}{c}0.1145^{* * * *} \\
(2.580) \\
\end{array}$ & $\begin{array}{c}0.2080^{* * * *} \\
(3.330) \\
\end{array}$ & $\begin{array}{c}-0.2266^{* * *} \\
(-3.705) \\
\end{array}$ \\
\hline $\mathrm{EO}<3$ & $\begin{array}{l}0.1472 \\
(1.641) \\
\end{array}$ & $\begin{array}{l}0.0005 \\
(0.087) \\
\end{array}$ & $\begin{array}{l}0.0056 \\
(1.369) \\
\end{array}$ & $\begin{array}{l}0.0257 \\
(1.268) \\
\end{array}$ & $\begin{array}{l}-0.0333 \\
(-1.432) \\
\end{array}$ & $\begin{array}{l}-0.0076 \\
(-0.229) \\
\end{array}$ & $\begin{array}{l}-0.0221 \\
(-0.643) \\
\end{array}$ \\
\hline $\mathrm{EO} \geq 10$ & $\begin{array}{c}-0.5196 * * * \\
(-2.764) \\
\end{array}$ & $\begin{array}{c}-0.0573 * * * \\
(-4.978) \\
\end{array}$ & $\begin{array}{c}-0.0265^{* * *} \\
(-3.106) \\
\end{array}$ & $\begin{array}{l}-0.0331 \\
(-0.848) \\
\end{array}$ & $\begin{array}{r}-0.0382 \\
(-0.544) \\
\end{array}$ & $\begin{array}{l}-0.0714 \\
(-0.840) \\
\end{array}$ & $\begin{array}{c}-0.1735^{* *} \\
(-2.188) \\
\end{array}$ \\
\hline FAM & $\begin{array}{c}0.0049 * * * \\
(3.277) \\
\end{array}$ & $\begin{array}{l}0.0001 \\
(0.704) \\
\end{array}$ & $\begin{array}{c}0.0001^{*} \\
(1.845) \\
\end{array}$ & $\begin{array}{l}-0.0005 \\
(-1.229) \\
\end{array}$ & $\begin{array}{l}-0.0006 \\
(-1.139) \\
\end{array}$ & $\begin{array}{l}-0.0011 \\
(-1.492) \\
\end{array}$ & $\begin{array}{c}-0.0017 * * \\
(-2.508) \\
\end{array}$ \\
\hline STATE & $\begin{array}{c}-0.002 \\
(-0.698) \\
\end{array}$ & $\begin{array}{c}-0.0004 * * \\
(-2.103) \\
\end{array}$ & $\begin{array}{c}-0.0006^{* * *} \\
(-4.432) \\
\end{array}$ & $\begin{array}{c}0.0019 * * \\
(2.297) \\
\end{array}$ & $\begin{array}{l}-0.0005 \\
(-0.965) \\
\end{array}$ & $\begin{array}{l}0.0014 \\
(1.313) \\
\end{array}$ & $\begin{array}{l}0.0415 \\
(1.132) \\
\end{array}$ \\
\hline $\begin{array}{l}\begin{array}{l}\text { Industry } \\
\text { dummies }\end{array} \\
\end{array}$ & Yes & Yes & Yes & Yes & Yes & Yes & Yes \\
\hline Year dummies & Yes & Yes & Yes & Yes & Yes & Yes & Yes \\
\hline Constant & $\begin{array}{c}2.0521 * * * \\
(5.525) \\
\end{array}$ & $\begin{array}{c}0.2240^{* * *} \\
(9.850) \\
\end{array}$ & $\begin{array}{c}0.1392 * * * \\
(8.273) \\
\end{array}$ & $\begin{array}{c}0.2814^{* * *} \\
(2.749) \\
\end{array}$ & $\begin{array}{l}0.1773 \\
(1.367) \\
\end{array}$ & $\begin{array}{c}0.4587 * * * \\
(2.679) \\
\end{array}$ & $\begin{array}{c}1.5961^{* * *} \\
(10.739) \\
\end{array}$ \\
\hline $\mathrm{R}^{2}$ & 0.26 & 0.27 & 0.24 & 0.21 & 0.07 & 0.14 & 0.19 \\
\hline Adjusted $\mathrm{R}^{2}$ & 0.23 & 0.24 & 0.21 & 0.18 & 0.04 & 0.11 & 0.17 \\
\hline $\mathrm{N}$ & 815 & 815 & 815 & 815 & 815 & 815 & 1,024 \\
\hline
\end{tabular}




\section{Appendix - Description of firm, ownership structure, and board variables}

This table explains the construction of the firm, ownership and board variables used in our regressions.

\begin{tabular}{|c|c|}
\hline BOARDSIZE & Number of directors on the board. Source: Registration documents. \\
\hline CAPEX & Ratio of capital expenditures to total assets. Source: Worldscope. \\
\hline COMMITTEES & Total number of standing board committees. Source: Registration documents. \\
\hline CREATION & Firm age, in years. Source: Registration documents, Diane. \\
\hline $\mathrm{CREP} / \mathrm{CF}$ & $\begin{array}{l}\text { Ratio of total cash dividends paid to common and preferred shareholders plus share repurchase amounts } \\
\text { to cash flow. Source: Worldscope. }\end{array}$ \\
\hline CREP/MV & $\begin{array}{l}\text { Ratio of total cash dividends paid to common and preferred shareholders plus share repurchase amounts } \\
\text { to market capitalization. Source: Worldscope. }\end{array}$ \\
\hline CREP/NETINC & $\begin{array}{l}\text { Ratio of total cash dividends paid to common and preferred shareholders plus share repurchase amounts } \\
\text { to net income. Source: Worldscope. }\end{array}$ \\
\hline DEMP & $\begin{array}{l}\text { Dummy variable equal to one if the firm has directors elected from among the employees on the board, } \\
\text { and zero otherwise. Source: Registration documents. }\end{array}$ \\
\hline DEMPLOYEES & $\begin{array}{l}\text { Dummy variable equal to one if the firm has employee directors on the board, and zero otherwise. } \\
\text { Source: Registration documents. }\end{array}$ \\
\hline DEMPSHARE & $\begin{array}{l}\text { Dummy variable equal to one if the firm has directors elected from among the employee-shareholders on } \\
\text { the board, and zero otherwise. Source: Registration documents. }\end{array}$ \\
\hline DIV/CF & $\begin{array}{l}\text { Ratio of total cash dividends paid to common and preferred shareholders to cash flow. Source: } \\
\text { Worldscope. }\end{array}$ \\
\hline ELIMINATION & $\begin{array}{l}\text { Dummy variable equal to one if elected employee directors were eliminated from the board between } \\
\text { years } N-1 \text { and } N \text {, and zero otherwise. Source: Registration documents. }\end{array}$ \\
\hline EO & $\begin{array}{l}\text { Ratio of the number of shares of all classes held by the employees to total shares outstanding (excluding } \\
\text { CEO ownership). Source: Registration documents. }\end{array}$ \\
\hline $\mathrm{EO}<3$ & $\begin{array}{l}\text { Dummy variable equal to one if the ratio of the number of shares of all classes held by the employees to } \\
\text { total shares outstanding is strictly positive and less than } 3 \% \text {, and zero otherwise. Source: Registration } \\
\text { documents. }\end{array}$ \\
\hline $\mathrm{EO} \geq 10$ & $\begin{array}{l}\text { Dummy variable equal to one if the ratio of the number of shares of all classes held by the employees to } \\
\text { total shares outstanding is higher than } 10 \% \text {, and zero otherwise. Source: Registration documents. }\end{array}$ \\
\hline FAM & $\begin{array}{l}\text { Ratio of the number of shares of all classes held by the founding families to total shares outstanding. } \\
\text { Source: Registration documents. }\end{array}$ \\
\hline GROWTH & Growth rate computed as percentage change in net sales between years $N-1$ and $N$. Source: Worldscope. \\
\hline INDUSTRY & Primary one-digit SIC code dummies. Source: Thomson One Banker, Diane. \\
\hline LEVERAGE & Leverage measured as total debt over total assets. Source: Worldscope. \\
\hline LSIZE & Natural log of the book value of total assets. Source: Worldscope. \\
\hline MEETINGS & $\begin{array}{l}\text { Annual number of board meetings (excludes actions by written consent of the directors and telephonic } \\
\text { meetings of the board). Source: Registration documents. }\end{array}$ \\
\hline MTB & $\begin{array}{l}\text { Market-to-book ratio measured as the market value of equity at the end of the fiscal year plus the book } \\
\text { value of total liabilities, all divided by the book value of total assets. Source: Worldscope. }\end{array}$ \\
\hline NB_YEARS_PRIV & Number of years since the privatization of the company. Source: Registration documents. \\
\hline PAYOUT & $\begin{array}{l}\text { Dividend payout ratio constructed as a ratio of total cash dividends paid to common and preferred } \\
\text { shareholders to net income. Source: Worldscope. }\end{array}$ \\
\hline PEMP & Fraction of directors elected from among the employees on the board. Source: Registration documents. \\
\hline PEMP_INDUSTRY & $\begin{array}{l}\text { Average fraction of directors elected from among the employees in the firm's industry. Source: } \\
\text { Registration documents. }\end{array}$ \\
\hline PEMPLOYEES & Fraction of employee directors on the board. Source: Registration documents. \\
\hline PEMPSHARE & $\begin{array}{l}\text { Fraction of directors elected from among the employee-shareholders on the board. Source: Registration } \\
\text { documents. }\end{array}$ \\
\hline
\end{tabular}




\begin{tabular}{|l|l|} 
PEMPSHARE_INDUSTRY & $\begin{array}{l}\text { Average fraction of directors elected from among the employee-shareholders in the firm's industry. } \\
\text { Source: Registration documents. }\end{array}$ \\
\hline POUTSIDERS & $\begin{array}{l}\text { Fraction of independent directors on the board, using the criteria presented by Viénot (1995, 1999) and } \\
\text { Bouton (2002). Source: Registration documents. }\end{array}$ \\
\hline PRIV & $\begin{array}{l}\text { Dummy variable equal to one if the firm is of fully or partially privatized companies, and zero otherwise. } \\
\text { Source: Registration documents. }\end{array}$ \\
\hline PWOMEN & Fraction of women directors on the board. Source: Registration documents. \\
\hline QTOBIN & $\begin{array}{l}\text { Tobin's Q defined as the market value of equity at the end of the fiscal year plus the book value of assets } \\
\text { minus the book value of equity, all divided by the book value of assets. Source: Worldscope. }\end{array}$ \\
\hline REP/CF & Ratio of share repurchase amounts to cash flow. Source: Worldscope. \\
\hline REP/MV & Ratio of share repurchase amounts to market capitalization. Source: Worldscope. \\
\hline REP/NETINC & Ratio of share repurchase amounts to net income. Source: Worldscope. \\
\hline ROA & $\begin{array}{l}\text { Return on Assets measured as operating income (alternatively using net income) over total assets. } \\
\text { Source: Worldscope. }\end{array}$ \\
\hline SIZE & Book value of total assets, euro millions. Source: Worldscope. \\
\hline STAFFCOSTS & $\begin{array}{l}\text { Wages paid to employees and officers of the company divided by the number of employees. Source: } \\
\text { Worldscope. }\end{array}$ \\
\hline STATE & $\begin{array}{l}\text { Ratio of the number of shares of all classes held by the French state to total shares outstanding. Source: } \\
\text { Registration documents. }\end{array}$ \\
\hline SUPERVISORY & $\begin{array}{l}\text { Dummy variable equal to one if the firm has a dual structure (Conseil de surveillance and Directoire), } \\
\text { and zero if the firm has a unique board of directors (Conseil d'administration). Source: Registration } \\
\text { documents. }\end{array}$ \\
\hline TANGIBLE & Ratio of tangible assets to total assets. Source: Worldscope. \\
\hline VOLAT & $\begin{array}{l}\text { Standard deviation of the monthly stock returns over the fiscal year immediately preceding the proxy } \\
\text { date. Source: Worldscope. }\end{array}$ \\
\hline YEAR & Year dummies. \\
\hline YIELD & $\begin{array}{l}\text { Ratio of total cash dividends paid to common and preferred shareholders to market capitalization. } \\
\text { Source: Worldscope. }\end{array}$ \\
\hline &
\end{tabular}

